\title{
Gender, assets, and market-oriented agriculture: learning from high-value crop and livestock projects in Africa and Asia
}

\author{
Agnes R. Quisumbing - Deborah Rubin - Cristina Manfre • \\ Elizabeth Waithanji · Mara van den Bold • Deanna Olney • \\ Nancy Johnson · Ruth Meinzen-Dick
}

Accepted: 22 December 2014/Published online: 1 February 2015

(C) Springer Science+Business Media Dordrecht 2015

\begin{abstract}
Strengthening the abilities of smallholder farmers in developing countries, particularly women farmers, to produce for both home and the market is currently a development priority. In many contexts, ownership of assets is strongly gendered, reflecting existing gender norms and limiting women's ability to invest in more profitable livelihood strategies such as market-oriented agriculture. Yet the intersection between women's asset endowments and their ability to participate in and benefit from agricultural interventions receives minimal attention. This paper explores changes in gender relations and women's assets in four agricultural interventions that promoted high value agriculture with different degrees of market-orientation. Findings suggest that these dairy and horticulture projects can successfully involve women and increase production, income and the stock of household assets. In some cases, women were able to increase their control over production, income and assets; however in most cases men's incomes increased more than women's and the gender-asset gap did not decrease. Gender- and asset-based barriers to participation in projects as well as gender norms that limit women's ability to accumulate and retain control over assets both contributed to the results. Comparing experiences across the four projects, especially
\end{abstract}

A. R. Quisumbing $(\bowtie) \cdot$ M. van den Bold · D. Olney ·

N. Johnson · R. Meinzen-Dick

International Food Policy Research Institute, Washington, DC,

USA

e-mail: a.quisumbing@cgiar.org

D. Rubin - C. Manfre

Cultural Practice, LLC, Bethesda, MD, USA

E. Waithanji

International Livestock Research Institute, Nairobi, Kenya where projects implemented adaptive measures to encourage gender-equitable outcomes, provides lessons for gender-responsive projects targeting existing and emerging value chains for high value products. Other targeted support to women farmers may also be needed to promote their acquisition of the physical assets required to expand production or enter other nodes of the value chain.

Keywords Gender - Value chains - Assets - Agricultural development projects $\cdot$ Impact evaluation · Food security
Abbreviations
E-HFP Enhanced Homestead Food Production
FGD Focus group discussion
GAAP Gender, Agriculture, and Assets Project
HFP Homestead Food Production
HKI Helen Keller International
LHW Livestock health worker
MSDDP Land O’Lakes Manica Smallholder Dairy
Development Project
NGO Non-governmental organization
OSP Orange sweet potato
REU HarvestPlus Reaching End Users
SDVC CARE's Strengthening the Dairy Value Chain
VFL Village farm leaders
VMF Village model farm
WEAI Women's Empowerment in Agriculture Index

\section{Introduction}

The design and implementation of agricultural development interventions is increasingly responding both to 
higher levels of donor-driven support for gender equality and to the growing body of evidence showing that women are productive farmers and agro-entrepreneurs when they have access to needed inputs (FAO 2011). Yet many efforts to enhance agricultural productivity and profitability have been limited in their ability to overcome existing gender disparities in participation and in accessing inputs or services. This is because agricultural interventions are embedded in social contexts that define the work that men and women do, the groups they join, and how resources and benefits are distributed. At the same time, efforts to promote high-value and market-oriented crop and livestock production have the potential to transform gender relations both within and outside the household. While there are many examples of how increasing market orientation of agriculture has harmed women, it may be possible that, with awareness of how value chains ${ }^{1}$ and systems of gender relations intersect, high-value production and achieving gender equity can be mutually supportive (Rubin and Manfre 2014).

A large body of research documents the roles of assets in economic development and poverty reduction (e.g., McKay and Perge 2013). Assets are acknowledged as critical resources for accumulating wealth and managing vulnerability. Beyond their direct economic effects, assets also influence the current and future well-being of an individual or household in other ways, such as improved future orientation and outlook on life, greater social empowerment, and enhanced civic and political engagement (Schreiner and Sherraden 2007). In many contexts, particularly rural areas of developing countries, men's and women's rights to use, control, and own assets are strongly gendered, reflecting existing gender norms and limiting women's ability to invest in more profitable livelihood strategies such as market-oriented agriculture. Despite their importance, few studies have looked at how agricultural interventions affect and are affected by the gendered distribution of assets in the target communities.

This paper reviews lessons from four impact evaluations of agricultural interventions in South Asia and Africa south of the Sahara that promoted high-value crops and livestock commodities embedded within emerging or existing value chains (Johnson et al. 2013; Quisumbing et al. 2013; van den Bold et al. 2013; Gilligan et al. 2014). The evaluations, which were part of the Gender, Agriculture, and Assets Project (GAAP), used mixed methods and looked at a

\footnotetext{
1 Value chains chart the sequence of actions and the organizational links that move a product or service through production, processing, marketing, and delivery to final consumers, to its consumption and disposal. Value chain analysis provides a focused process of data collection and interpretation to understand the new forms of connectivity between producers, buyers, and consumers in today's global food system (Kaplinsky and Morris 2000).
}

range of development outcomes, including women's ownership and control of assets. ${ }^{2}$ While the four projects differed in their objectives and approaches-in terms of both gender-sensitivity and market orientation-the focus on high-value agriculture and collection of sex-disaggregated data allows us to explore how women participate in and benefit from projects that offer significant increases in the value of production but also require greater capital and labor inputs into production. Specifically, this paper examines

1. How initial asset endowments of men and women affect their ability to participate in and benefit from agricultural development projects that promote high value crops and livestock;

2. How agricultural interventions have facilitated or impeded men's and women's abilities to benefit from project interventions, including their ability to accumulate assets; and,

3. What these initial results imply for value chain development, considering the different social, economic, and cultural contexts in which these interventions operate.

We find that underlying patterns of asset use, ownership, and control condition men's and women's abilities to participate in and benefit from projects promoting highvalue agricultural commodities. Initial gender differences in asset ownership and control may affect the take-up of interventions as well as their subsequent impact. Projects can be consciously designed to counter existing gender disparities, but may also unintentionally exacerbate gender asset gaps.

The remaining sections of the paper are organized as follows. The next section describes the conceptual framework followed by the four case studies. Findings from two commercially-oriented projects and lessons from two projects that promoted high-value crops and livestock for nutrition follow. The final section discusses implications for gender-responsive program design, especially in the area of high-value agriculture and value chain development.

\footnotetext{
$\overline{2}$ GAAP was a capacity building and evaluation initiative led by the International Food Policy Research Institute (IFPRI) and the International Livestock Research Institute (ILRI), aimed to better understand gender and asset dynamics in agricultural development programs. The project worked with nine agricultural interventions implemented by different partners in South Asia and Africa south of the Sahara. Although building women's assets may not have been among the original objectives of the interventions, GAAP used both quantitative and qualitative methods to assess project impacts on the distribution of assets within households and to identify approaches to address gender inequalities and improving outcomes for women and men.
} 
A conceptual framework for understanding gendered use, control, and ownership of assets

Attention to assets in the gender literature is a relatively new area of inquiry (e.g., Deere and Doss 2006; Meinzen-Dick et al. 2011). Testing models of household behavior dismantled the idea of the unitary household, leading to a more nuanced understanding that incomes are not always pooled within households but can be held and managed separately by individuals (Haddad et al. 1997). Each household member may have different use, control, and ownership rights to different types and levels of assets and may have obtained them through different pathways, conditioned by social norms and beliefs, including those related to gender. Individuals' asset holdings may also have different implications for bargaining power within the household.

Our conceptual framework (Fig. 1) shows the links between assets and well-being while making clear that gender relations influence the constraints and opportunities that occur in each pathway (Meinzen-Dick et al. 2011). Each component of the framework is gendered. Women and men often have separate assets, activities, and incomes that they use to meet individual consumption, investment, and saving objectives, in line with their own priorities and with their responsibilities within their households and communities. Households can also have joint assets, strategies, consumption, and investment priorities. The shading of each box reminds us that we need to consider separation and jointness in each component. The framework defines assets broadly, as tangible (e.g., physical and natural capital) and intangible assets (e.g., social capital, human capital), and maps the gendered pathways through which asset accumulation occurs. It includes not only men's and women's exclusively owned assets, but also assets whose control and ownership is held jointly.
In this framework, tangible and intangible assets determine livelihood strategies. Subject to the realization of unexpected positive or negative events (shocks), these livelihood strategies generate full incomes, which can be consumed or saved/invested. Full incomes do not only include monetary incomes and income in-kind, but also the value of time - an important resource that, if overlooked, tends to underestimate women's contributions. Allocation of full income to consumption or savings results in improved well-being outcomes such as health, nutrition, self-esteem, and empowerment. This entire process is nested within a context, the set of ecological, social, economic, and political institutions that determine societal and gender norms. The dotted arrow also indicates that assets can directly affect well-being if, for example, there is status or self-esteem associated with asset ownership. The direction of causation does not only go from assets to well-being: livelihood strategies also affect the assets that individuals choose to hold, and savings and investments determine the future size and composition of the asset portfolio.

The framework can be used to look at many types of interventions. There were two main types among the nine agricultural development projects included in GAAP. The first were projects that distributed assets to beneficiaries, thus directly affecting the Asset box in the framework. The second type of projects influenced the Livelihood Strategies box by making information or technologies available that altered the returns that households received from their existing assets. Some interventions did both.

\section{Four high-value agricultural project interventions}

This paper synthesizes results of the evaluations of four interventions. The first case study is phase one of the Land
Fig. 1 The GAAP conceptual framework

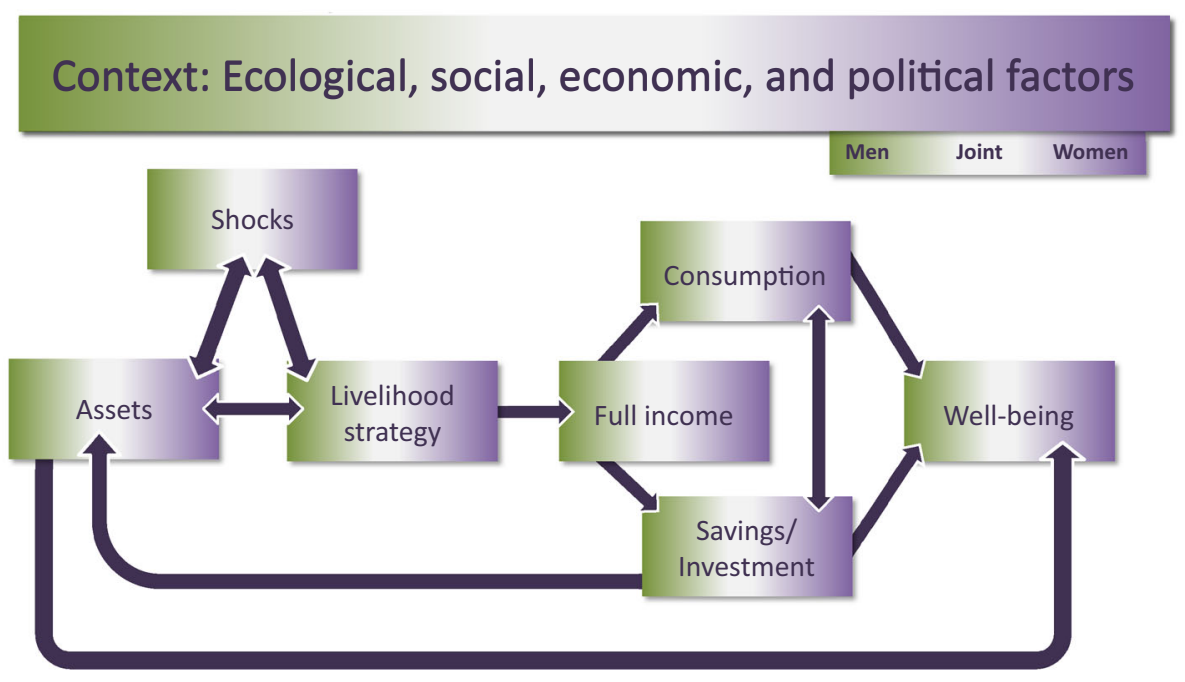


O'Lakes Manica Smallholder Dairy Development Project (MSDDP) (2008-2012), funded by the United States Department of Agriculture. ${ }^{3}$ Implemented in Manica Province, Mozambique, it aimed to rebuild Mozambique's dairy industry to meet market demand and to increase incomes for smallholder farmers by participating in a sustainable dairy value chain. The program provided training in soil conservation, milk collection, marketing, and animal husbandry techniques. It set up three milk collection, processing, and distribution centers and helped establish 11 dairy associations and three dairy cooperatives. The project distributed 500 jersey cows. Beneficiary households qualified to receive a cow according to established criteria: commitment of two household members to attend all the prescribed trainings; possession of adequate access to land and water to maintain the cow; proximity to a milk collection center; active participation in a community group or cooperative; and the planting of pasture and fodder crops prior to receiving the dairy cow. The evaluation compared those who had already received cows with those who had been selected to receive cows but had not yet received one (Johnson et al. 2013).

The second case study, CARE's Strengthening the Dairy Value Chain (SDVC) project, worked with 35,000 smallholder dairy farmers in northwest Bangladesh to improve their dairy-related incomes (Ahmed et al. 2009; Alam et al. 2011; Quisumbing et al. 2013). From 2007 to 2012, it aimed to reduce key constraints to smallholder participation in the value chain: lack of farmer knowledge and coordination, weak milk markets, and limited access to productive inputs. Working in areas served by existing chilling plants, the project helped to create dairy farmer associations, mostly formed by poor women smallholder dairy farmers, and provided training in dairy management skills and business management to their members. The project also set up within-village milk collection centers and shops selling inputs for livestock-raising. The project also aimed to increase women's employment along the value chain, particularly in jobs where they were typically underrepresented (as input suppliers, livestock health workers (LHW), or artificial insemination technicians). The evaluation used two counterfactual comparison groups (eligible non-beneficiary farmers in areas with chilling plants where SVDC operated and eligible farmers in areas without milk chilling plants).

Lessons from the third case study, the Helen Keller International (HKI)'s Enhanced Homestead Food Production (E-HFP) program in Gourma Province, Burkina Faso (2010-2012), can be useful for projects promoting vegetable and small livestock. ${ }^{4}$ The goal of the E-HFP project

\footnotetext{
${ }^{3}$ See Johnson et al. (2013) for details.

${ }^{4}$ See van den Bold et al. (2013) for details.
}

was to improve infant, young child, and maternal health and nutrition outcomes through a set of nutrition and production interventions targeted to women (Berhman et al. 2011). Targeting women with children between 3 and 12 months of age at baseline in 2010, it set out to achieve this through (1) increasing the availability of micronutrient-rich foods through increased food production by women; (2) income generation through the sale of surplus production; and (3) increased knowledge and adoption of optimal nutrition practices, including the consumption of micronutrient-rich foods. The program was also expected to improve child and maternal nutrition through the influence of enhanced women's empowerment and status, including their access to and control over resources. HKI worked with community leaders to identify and obtain rights to plots of land that could be used by women village farm leaders (VFLs) to set up a village model farm (VMF). ${ }^{5}$ The VMF functioned as the program's demonstration site and as a place for training participating women on setting up home gardens, small animal rearing, and irrigation. The program also provided mothers with inputs (chickens, seeds, and gardening materials, and goats in some of the villages) to start their own gardens at home. Furthermore, the program trained community members who in turn trained beneficiary women in agriculture and improved nutrition practices through their behavior change communications strategy. The impacts of the program were evaluated by a quantitative longitudinal impact evaluation that used a randomized control trial design (baseline 2010, endline 2012), supplemented by two rounds of qualitative research $(2011,2012){ }^{6}$

The final project is the HarvestPlus "Reaching End Users" (REU) project, which introduced biofortified orange sweet potato (OSP) in Uganda in 2007 to increase dietary intakes of vitamin A and reduce the prevalence of vitamin A deficiency (de Brauw et al. 2010). Similar to the HKI project, the REU project is not, strictly speaking, a value-chain project but one that introduces a high-value, nutritionally dense commodity. OSP, developed by HarvestPlus, is a dense source of vitamin A and is moderately higher yielding compared to conventional white or yellow sweet potato varieties typically grown in Uganda. The REU project engaged existing farmers' groups, which were composed largely or entirely of women, in a multipronged intervention, including free vine distribution to members of selected project farmer groups; trainings of farmer group

\footnotetext{
5 This was done in anticipation of the risk that husbands would take control of the land once income generation increased.

${ }^{6}$ Villages were selected into 30 intervention villages and 25 control villages for the impact evaluation. For the qualitative research, a subsample of households was randomly selected from the 30 intervention villages and from 15 of the 15 control villages (van den Bold et al. 2013).
} 
members on OSP cultivation; trainings of adult women in project households on the nutritional benefits of OSP; and trainings of farmer group members on marketing. The project also included a randomized control trial-based component to test and document the most cost-effective method to disseminate OSP and encourage its consumption.

Tables presented in this paper show both baseline and endline variables for treatment and control groups, as well as tests of difference between means between baseline and endline for each group, but these should not be interpreted as impact estimates, which can be found in the specific papers that this paper synthesizes.

\section{Gender and asset dynamics in dairy value chains: Mozambique and Bangladesh}

Both productivity and consumption are low in Mozambique's dairy industry. Part of this is due to the unfavorable agroecological conditions, although other factors, such as the country's long civil war, also play a part. Milk production was lower in 2006 than it was in 1980 (Zvomuya 2009), and projects such as MSDDP are working to rebuild the country's dairy industry in a way that benefits smallholder farmers and link them to the market. In Manica province, the project area, agriculture is the primary household income-generating activity and earnings from dairy and meat sales are the second most important source of income for rural households after sales of crops.

Cattle are typically considered to be men's property, except where women are household heads (Nhambeto and Hutchinson 2011). While women do own fewer cows than men $(0.23$ for women compared to 3.08 for men in the treatment group, and no cows and 1.58 for men in the control group at baseline), the data from baseline and endline surveys show joint ownership of cattle is high, with joint ownership of 1.47 cows, on average, in the treatment group and 2.5 cows in the control group, respectively, at baseline (Table 1). For other types of assets, women's individual ownership is low, but the majority of household and productive durables ${ }^{7}$ are jointly owned. The majority of household assets are owned by men, reflecting the importance of transportation assets that are mainly owned by men (Table 2). ${ }^{8}$ The total asset index for men had values of 14.95 and 20.32 in the treatment and control groups at baseline, respectively, whereas women had only 3.35 and 0.32 in the treatment and control groups. There

\footnotetext{
7 This category includes hoes, spades/shovels, plows, water pumps, sprayer pumps, and sewing machines. The latter are considered productive assets for those owning a tailoring business.

8 This category includes cars/trucks, motorcycles, bicycles, and carts.
}

was substantial ownership of joint assets in the treatment group, with index values of 22.96 compared to 12.88 in the control group at baseline.

Ownership data reflect an individual respondent's perception of who owns assets. Focus group discussions (FGDs) revealed that in many cases, people defined ownership according to whether someone could use an asset. More stringent definitions, such as ability to loan, sell, or to bequeath the asset in case of death or divorce, often favored men. These findings show that asset ownership can be more complex and nuanced, which is rarely reflected in how projects distribute assets or how they define assetbased participation criteria. In MSDDP, there were no significant impacts on major categories of asset ownership; however, there was a significant increase in "exotic" cattle owned by men (Johnson et al. 2013). This likely reflects the fact that the cows distributed through MSDDP were registered, following project rules, to the household head, who was a man in over $90 \%$ of cases. This is supported by data in Table 1 indicating that men's (but not women's) cow ownership increased significantly at endline in the treatment group. Men (but not women) in the treatment group were also able to increase their ownership of household durables and agricultural durables significantly.

Prior to MSDDP, women had a limited role in cattle management. This situation changed with the MSDDP, in which women and even children were expected to contribute labor to the cows' upkeep. The highly productive cattle distributed by the MSDDP produced much more milk than traditional cows but required more and better food and other inputs. Because they did not graze, food and water had to be brought to the cow, which dramatically increased labor requirements. Data from FGDs highlighted that men and women in project areas have different responsibilities in livestock care and management as well as milk production and marketing. Men typically prepare forage plots and pasture areas, build enclosures for their animals, cut grass for feed, purchase supplementary rations, clean cow teats, take milk to the collection centers, and report sick cows to veterinary technicians. Women typically feed and water cows, collect fodder, make minor repairs on cattle enclosures, sell milk in local markets, and hand-dress cows (e.g., remove ticks). Both men and women may clean enclosures and/or change dirty water. The need to involve multiple household members was the reason behind requiring two household members to attend the trainings. The project initially required just the household head to attend but project staff observed that in some cases, the cows were not being properly cared for and therefore increased the number of household members required to attend training. As a result of the change, over $60 \%$ of trainees ended up being women. Men and women received the same training. Men contribute the majority of labor to 
Table 1 Household livestock holdings and land cultivated by gender, baseline and follow-up, by treatment status, Mozambique

\begin{tabular}{|c|c|c|c|c|c|c|}
\hline & \multicolumn{2}{|c|}{ Baseline (2009) } & \multicolumn{2}{|c|}{ Follow up (2011) } & \multicolumn{2}{|c|}{$\begin{array}{l}t \text {-test of difference of baseline } \\
\text { and follow-up means ( } p \text {-value) }\end{array}$} \\
\hline & $\begin{array}{l}\text { Treatment } \\
(\mathrm{N}=100)\end{array}$ & $\begin{array}{l}\text { Control } \\
(\mathrm{N}=25)\end{array}$ & $\begin{array}{l}\text { Treatment } \\
(\mathrm{N}=100)\end{array}$ & $\begin{array}{l}\text { Control } \\
(\mathrm{N}=25)\end{array}$ & Treatment & Control \\
\hline \multicolumn{7}{|c|}{ Land cultivated (acres) } \\
\hline Men & $\begin{array}{l}3.17 \\
(4.07)\end{array}$ & $\begin{array}{l}2.77 \\
(3.17)\end{array}$ & $\begin{array}{l}3.17 \\
(4.07)\end{array}$ & $\begin{array}{l}2.77 \\
(3.17)\end{array}$ & - & - \\
\hline Women & $\begin{array}{l}0.76 \\
(1.50)\end{array}$ & $\begin{array}{l}0.53 \\
(1.20)\end{array}$ & $\begin{array}{l}0.76 \\
(1.20)\end{array}$ & $\begin{array}{l}0.53 \\
(1.20)\end{array}$ & - & - \\
\hline Jointly & $\begin{array}{l}1.00 \\
(2.65)\end{array}$ & $\begin{array}{l}0.46 \\
(1.92)\end{array}$ & $\begin{array}{l}1.00 \\
(2.65)\end{array}$ & $\begin{array}{l}0.46 \\
(1.92)\end{array}$ & - & - \\
\hline \multicolumn{7}{|l|}{ Cattle } \\
\hline Men & $\begin{array}{l}3.08 \\
(5.83)\end{array}$ & $\begin{array}{l}1.58 \\
(4.23)\end{array}$ & $\begin{array}{l}3.46 \\
(6.23)\end{array}$ & $\begin{array}{l}1.63 \\
(3.34)\end{array}$ & 0.00 & 0.88 \\
\hline Women & $\begin{array}{l}0.23 \\
(1.24)\end{array}$ & $\begin{array}{l}0.00 \\
(0.00)\end{array}$ & $\begin{array}{l}0.20 \\
(1.43)\end{array}$ & $\begin{array}{l}0.00 \\
(0.00)\end{array}$ & 0.10 & - \\
\hline Jointly & $\begin{array}{l}1.47 \\
(3.26)\end{array}$ & $\begin{array}{l}2.50 \\
(6.85)\end{array}$ & $\begin{array}{l}1.53 \\
(3.22)\end{array}$ & $\begin{array}{l}2.50 \\
(6.85)\end{array}$ & 0.45 & - \\
\hline
\end{tabular}

Means and standard deviations (in parentheses)

- Types of assets where there was no reported change between the baseline and follow-up, so $p$-values could not be computed

the dairy enterprise; however, the increase in women's labor contribution to cattle keeping was much bigger than men's, since it started from a much lower level (Johnson et al. 2013). Women reported that it was challenging to manage their time, given the new demands, resulting in less time to meet with other community members and more delegation of tasks to other household members, such as children.

In spite of women's role in taking care of the cows, FGDs with members of households that had received their cows reported that men remained the ultimate decisionmakers on most cattle or dairy-related issues, e.g., with regards to input use, production practices, technologies adopted, attendance at trainings, joining a cooperative or association; or registration for cow distribution. Women were often consulted and reported satisfaction in having their knowledge and skills recognized within their households, but men retained final authority. Having had a woman as a trainee is positively associated with dairy income; however, both men and women report that men control the majority of the income from dairy production (Johnson et al. 2013). Household dairy income increased in participant households; however, the majority of the income was controlled by men.

The Land O' Lakes project was not sensitive to gender issues in designing its Phase 1 project, but adopted new strategies based on findings from the GAAP initial assessment. By introducing the dairy cow as a household asset, the project led to women's increased involvement in dairy management. This, in turn, resulted in women being consulted more by men regarding decisions about household dairy businesses. These lessons have been considered by Land O'Lakes in planning the second phase of its project, which will pay greater attention to involving women at the household level and within dairy associations and cooperatives (Nhambeto, personal communication).

Although the dairy value chain project in Bangladesh operated in a very different social and cultural context, it was similar to the Mozambique project in that it also operated in a relatively poor and isolated area, where men owned most of the household assets and dairy cows were considered men's property. Table 3 presents the distribution of land and asset ownership within surveyed households in the baseline (2008) and endline (2012) survey rounds. In the project area, the Bogra and Rangpur districts of Bangladesh, land is almost exclusively owned by the husband, with a small portion owned by the wife (in wealthier households) and an even smaller portion of land owned jointly. To illustrate, at baseline, husbands in treatment households owned 63.55 decimals of land, wives owned 4.41 decimals, and only 0.29 decimals were owned jointly (100 decimals $=1$ acre). Patterns are similar in control households. This reflects the patrilineal inheritance regime and the practice of partible inheritance, where the father's property is divided among many heirs, as well as Sharia law, where sons inherit twice the share of daughters. 
Table 2 Household durables and agricultural assets at household level by gender, baseline and follow-up, by treatment status, Mozambique

\begin{tabular}{|c|c|c|c|c|c|c|}
\hline & \multicolumn{2}{|c|}{ Baseline (2009) } & \multicolumn{2}{|c|}{ Follow-up (2011) } & \multicolumn{2}{|c|}{$\begin{array}{l}t \text {-test of difference of baseline } \\
\text { and follow-up means ( } p \text {-value) }\end{array}$} \\
\hline & $\begin{array}{l}\text { Treatment } \\
(\mathrm{N}=100)\end{array}$ & $\begin{array}{l}\text { Control } \\
(\mathrm{N}=25)\end{array}$ & $\begin{array}{l}\text { Treatment } \\
(\mathrm{N}=100)\end{array}$ & $\begin{array}{l}\text { Control } \\
(\mathrm{N}=25)\end{array}$ & $\begin{array}{l}\text { Treatment } \\
(\mathrm{N}=100)\end{array}$ & $\begin{array}{l}\text { Control } \\
(\mathrm{N}=25)\end{array}$ \\
\hline \multicolumn{7}{|c|}{ Household durables: index } \\
\hline Men & $\begin{array}{l}2.72 \\
(4.04)\end{array}$ & $\begin{array}{l}2.95 \\
(7.66)\end{array}$ & $\begin{array}{l}3.83 \\
(4.71)\end{array}$ & $\begin{array}{l}3.21 \\
(7.68)\end{array}$ & 0.00 & 0.10 \\
\hline Women & $\begin{array}{l}0.83 \\
(2.75)\end{array}$ & $\begin{array}{l}0.21 \\
(0.71)\end{array}$ & $\begin{array}{l}0.86 \\
(2.75)\end{array}$ & $\begin{array}{l}0.21 \\
(0.71)\end{array}$ & 0.18 & - \\
\hline Jointly & $\begin{array}{l}5.32 \\
(6.79)\end{array}$ & $\begin{array}{l}6.21 \\
(4.65)\end{array}$ & $\begin{array}{l}5.32 \\
(6.79)\end{array}$ & $\begin{array}{l}6.21 \\
(4.65)\end{array}$ & - & - \\
\hline \multicolumn{7}{|c|}{ Agricultural durables: index } \\
\hline Men & $\begin{array}{l}2.28 \\
(4.85)\end{array}$ & $\begin{array}{l}2.56 \\
(4.00)\end{array}$ & $\begin{array}{l}3.32 \\
(6.13)\end{array}$ & $\begin{array}{l}3.52 \\
(6.27)\end{array}$ & 0.00 & 0.26 \\
\hline Women & $\begin{array}{l}0.13 \\
(0.68)\end{array}$ & $\begin{array}{l}0.16 \\
(0.80)\end{array}$ & $\begin{array}{l}0.14 \\
(0.72)\end{array}$ & $\begin{array}{l}0.16 \\
(0.80)\end{array}$ & 0.32 & - \\
\hline Jointly & $\begin{array}{l}7.78 \\
(8.21)\end{array}$ & $\begin{array}{l}5.76 \\
(3.86)\end{array}$ & $\begin{array}{l}7.80 \\
(8.24)\end{array}$ & $\begin{array}{l}5.76 \\
(3.86)\end{array}$ & 0.32 & - \\
\hline \multicolumn{7}{|c|}{ Total assets: index } \\
\hline Men & $\begin{array}{l}14.95 \\
(29.25)\end{array}$ & $\begin{array}{l}20.32 \\
(39.40)\end{array}$ & $\begin{array}{l}19.41 \\
(32.41)\end{array}$ & $\begin{array}{l}21.72 \\
(39.96)\end{array}$ & 0.00 & 0.13 \\
\hline Women & $\begin{array}{l}3.35 \\
(13.33)\end{array}$ & $\begin{array}{l}0.32 \\
(0.99)\end{array}$ & $\begin{array}{l}3.79 \\
(15.31)\end{array}$ & $\begin{array}{l}0.320 \\
(0.99)\end{array}$ & 0.93 & - \\
\hline Jointly & $\begin{array}{l}22.96 \\
(46.31)\end{array}$ & $\begin{array}{l}12.88 \\
(10.57)\end{array}$ & $\begin{array}{l}22.98 \\
(46.33)\end{array}$ & $\begin{array}{l}12.88 \\
(10.57)\end{array}$ & 0.32 & - \\
\hline
\end{tabular}

Means and standard deviations (in parentheses)

- Types of assets where there was no reported change between the baseline and follow-up, so $p$-values could not be computed

Cattle, jewelry, and consumer durables are the most valuable assets owned jointly by the household. Although jewelry is typically regarded as a woman's asset in Bangladesh and cattle is regarded as men's property, when respondents are allowed to report joint asset ownership, they report high proportions of these assets that are jointly owned. While women do own some cattle, the value is much less than that owned by husbands or held jointly-on average, at baseline, women owned less than 5,000 taka worth of cattle in both treatment and control households, which is much less than what husbands own (around 19,000 taka and 16,000 taka in treatment and control households, respectively) and also less than the value of jointly owned cattle (about 13,000 taka in treatment households and 17,000 taka in control households). Moreover, ownership does not necessarily translate to control over these jointly owned items; men report rights to decide whether to buy or sell even jointly-held livestock (Ahmed et al. 2009). Local cows are less productive than improved, more expensive breeds; their productivity is limited by low quality fodder and poor feeding practices (Ahmed et al. 2009).

Both baseline and endline surveys revealed that women carry out the main daily activities related to milk production in most households. Although women provide most of the labor for daily livestock-rearing activities, they made care and sales decisions in only $20 \%$ of cases. Nearly $80 \%$ of the husbands were reported to be the primary decisionmakers on buying, selling, or leasing a dairy cow (Ahmed et al. 2009).

In the Bangladesh site, prior to the SDVC project, few women sold milk regularly. The project's identification and training of milk collectors significantly expanded women's outlets for milk sales. Owing to the value placed on female seclusion, women were reluctant to travel long distances to take milk to the market. Under the project, the milk collectors collect milk from door-to-door daily and return with payments weekly or monthly. Milk collection centers are also located within villages, and collected milk is then taken to a local chilling plant. Women use income from 
Table 3 Asset ownership by gender in Bangladesh, baseline and endline and 2012, by treatment status

\begin{tabular}{|c|c|c|c|c|c|c|}
\hline & \multicolumn{2}{|c|}{ Baseline (2008) } & \multicolumn{2}{|c|}{ Endline (2012) } & \multicolumn{2}{|c|}{$\begin{array}{l}t \text {-test of difference of baseline } \\
\text { and endline means ( } p \text {-value) }\end{array}$} \\
\hline & Treatment & Control & Treatment & Control & Treatment & Control \\
\hline \multicolumn{7}{|l|}{ Land owned (decimals) ${ }^{\mathrm{a}}$} \\
\hline Land owned by husband & $\begin{array}{l}63.55 \\
(108.31)\end{array}$ & $\begin{array}{l}62.34 \\
(102.67)\end{array}$ & $\begin{array}{l}61.03 \\
(91.18)\end{array}$ & $\begin{array}{l}58.43 \\
(87.00)\end{array}$ & 0.23 & 0.08 \\
\hline Land owned by wife & $\begin{array}{l}4.41 \\
(23.30)\end{array}$ & $\begin{array}{l}3.48 \\
(19.97)\end{array}$ & $\begin{array}{l}3.92 \\
(24.18)\end{array}$ & $\begin{array}{l}3.30 \\
(20.66)\end{array}$ & 0.51 & 0.06 \\
\hline Land owned jointly & $\begin{array}{l}0.29 \\
(3.71)\end{array}$ & $\begin{array}{l}0.31 \\
(3.83)\end{array}$ & $\begin{array}{l}0.26 \\
(3.71)\end{array}$ & $\begin{array}{l}0.32 \\
(3.68)\end{array}$ & 0.88 & 0.60 \\
\hline \multicolumn{7}{|l|}{ Value of livestock owned (in 2008 taka) } \\
\hline Cattle owned by husband & $\begin{array}{l}18,919.69 \\
(30,749.94)\end{array}$ & $\begin{array}{l}16,455.07 \\
(27,724.48)\end{array}$ & $\begin{array}{l}21,867.37 \\
(46,748.58)\end{array}$ & $\begin{array}{l}22,530.57 \\
(45,516.66)\end{array}$ & 0.22 & 0.31 \\
\hline Cattle owned by wife & $\begin{array}{l}4,677.95 \\
(13,915.35)\end{array}$ & $\begin{array}{l}4,367.71 \\
(12,876.76)\end{array}$ & $\begin{array}{l}5,303.58 \\
(26,952.39)\end{array}$ & $\begin{array}{l}4,896.59 \\
(23,510.62)\end{array}$ & 0.56 & 0.14 \\
\hline Cattle owned jointly & $\begin{array}{l}13,241.10 \\
(30,218.99)\end{array}$ & $\begin{array}{l}16,760.82 \\
(34,734.04)\end{array}$ & $\begin{array}{l}9,699.02 \\
(48,012.05)\end{array}$ & $\begin{array}{l}9,814.44 \\
(42,972.64)\end{array}$ & 0.08 & 0.51 \\
\hline Goats owned by husband & $\begin{array}{l}529.84 \\
(1,543.20)\end{array}$ & $\begin{array}{l}457.93 \\
(1,359.74)\end{array}$ & $\begin{array}{l}523.78 \\
(2,218.87)\end{array}$ & $\begin{array}{l}447.10 \\
(1,931.16)\end{array}$ & 0.82 & 0.04 \\
\hline Goats owned by wife & $\begin{array}{l}229.45 \\
(981.95)\end{array}$ & $\begin{array}{l}206.67 \\
(890.73)\end{array}$ & $\begin{array}{l}606.19 \\
(1,827.04)\end{array}$ & $\begin{array}{l}625.62 \\
(1,711.65)\end{array}$ & 0.00 & 0.00 \\
\hline Goats owned jointly & $\begin{array}{l}407.17 \\
(1,528.40)\end{array}$ & $\begin{array}{l}486.60 \\
(1,624.19)\end{array}$ & $\begin{array}{l}124.43 \\
(774.99)\end{array}$ & $\begin{array}{l}106.43 \\
(724.45)\end{array}$ & 0.00 & 0.02 \\
\hline Poultry owned by husband & $\begin{array}{l}235.35 \\
(701.09)\end{array}$ & $\begin{array}{l}212.95 \\
(626.97)\end{array}$ & $\begin{array}{l}223.91 \\
(637.46)\end{array}$ & $\begin{array}{l}214.76 \\
(618.80)\end{array}$ & 0.64 & 0.74 \\
\hline Poultry owned by wife & $\begin{array}{l}305.83 \\
(816.26)\end{array}$ & $\begin{array}{l}269.46 \\
(733.71)\end{array}$ & $\begin{array}{l}587.57 \\
(927.99)\end{array}$ & $\begin{array}{l}586.50 \\
(1,009.82)\end{array}$ & 0.00 & 0.00 \\
\hline Poultry owned jointly & $\begin{array}{l}299.17 \\
(1,721.71)\end{array}$ & $\begin{array}{l}281.27 \\
(1,611.80)\end{array}$ & $\begin{array}{l}46.78 \\
(263.59)\end{array}$ & $\begin{array}{l}51.79 \\
(298.75)\end{array}$ & 0.00 & 0.01 \\
\hline \multicolumn{7}{|l|}{ Value of nonland assets owned (2008 taka) } \\
\hline Consumption durables owned by husband & $\begin{array}{l}3,954.87 \\
(7,160.79)\end{array}$ & $\begin{array}{l}4,000.13 \\
(7,579.46)\end{array}$ & $\begin{array}{l}7,116.69 \\
(12,743.08)\end{array}$ & $\begin{array}{l}7,018.50 \\
(13,277.81)\end{array}$ & 0.00 & 0.00 \\
\hline Consumption durables owned by wife & $\begin{array}{l}611.68 \\
(2,170.30)\end{array}$ & $\begin{array}{l}530.85 \\
(1,987.87)\end{array}$ & $\begin{array}{l}1,100.04 \\
(4,045.94)\end{array}$ & $\begin{array}{l}1,062.42 \\
(3,613.22)\end{array}$ & 0.01 & 0.13 \\
\hline Consumption durables owned jointly & $\begin{array}{l}3,402.46 \\
(9,661.16)\end{array}$ & $\begin{array}{l}3,384.04 \\
(9,444.18)\end{array}$ & $\begin{array}{l}3,281.38 \\
(7,186.20)\end{array}$ & $\begin{array}{l}3,114.74 \\
(6,687.92)\end{array}$ & 0.64 & 0.01 \\
\hline Jewelry owned by husband & $\begin{array}{l}895.88 \\
(4,520.33)\end{array}$ & $\begin{array}{l}799.37 \\
(4,430.68)\end{array}$ & $\begin{array}{l}2,839.45 \\
(16,952.90)\end{array}$ & $\begin{array}{l}2,281.70 \\
(14,607.37)\end{array}$ & 0.01 & 0.16 \\
\hline Jewelry owned by wife & $\begin{array}{l}2,262.66 \\
(7,782.20)\end{array}$ & $\begin{array}{l}2,298.82 \\
(8,319.02)\end{array}$ & $\begin{array}{l}7,812.85 \\
(20,281.93)\end{array}$ & $\begin{array}{l}7,859.03 \\
(21,338.11)\end{array}$ & 0.00 & 0.00 \\
\hline Jewelry owned jointly & $\begin{array}{l}2,561.54 \\
(12,555.49)\end{array}$ & $\begin{array}{l}3,001.83 \\
(12,336.21)\end{array}$ & $\begin{array}{l}3,268.89 \\
(17,054.16)\end{array}$ & $\begin{array}{l}2,860.87 \\
(15,420.15)\end{array}$ & 0.43 & 0.26 \\
\hline Agricultural durables owned by husband & $\begin{array}{l}1,544.79 \\
(6,313.35)\end{array}$ & $\begin{array}{l}1,596.52 \\
(7,623.52)\end{array}$ & $\begin{array}{l}2,793.51 \\
(11,225.06)\end{array}$ & $\begin{array}{l}2,475.44 \\
(9,660.24)\end{array}$ & 0.02 & 0.75 \\
\hline Agricultural durables owned by wife & $\begin{array}{l}49.43 \\
(587.34)\end{array}$ & $\begin{array}{l}43.83 \\
(502.69)\end{array}$ & $\begin{array}{l}228.46 \\
(4,948.86)\end{array}$ & $\begin{array}{l}165.76 \\
(4,165.64)\end{array}$ & 0.37 & 0.51 \\
\hline Agricultural durables owned jointly & $\begin{array}{l}944.29 \\
(3,806.65)\end{array}$ & $\begin{array}{l}1,268.35 \\
(4,559.82)\end{array}$ & $\begin{array}{l}456.42 \\
(2,143.29)\end{array}$ & $\begin{array}{l}488.21 \\
(2,289.84)\end{array}$ & 0.00 & 0.29 \\
\hline
\end{tabular}


Table 3 continued

\begin{tabular}{|c|c|c|c|c|c|c|}
\hline & \multicolumn{2}{|c|}{ Baseline (2008) } & \multicolumn{2}{|c|}{ Endline (2012) } & \multicolumn{2}{|c|}{$\begin{array}{l}t \text {-test of difference of baseline } \\
\text { and endline means ( } p \text {-value) }\end{array}$} \\
\hline & Treatment & Control & Treatment & Control & Treatment & Control \\
\hline Nonagricultural durables owned by husband & $\begin{array}{l}814.52 \\
(4,672.46)\end{array}$ & $\begin{array}{l}760.05 \\
(4,192.84)\end{array}$ & $\begin{array}{l}669.86 \\
(4,693.44)\end{array}$ & $\begin{array}{l}583.11 \\
(3,997.25)\end{array}$ & 0.57 & 0.45 \\
\hline Nonagricultural durables owned by wife & $\begin{array}{l}62.90 \\
(557.32)\end{array}$ & $\begin{array}{l}45.93 \\
(470.47)\end{array}$ & $\begin{array}{l}92.49 \\
(1,436.75)\end{array}$ & $\begin{array}{l}72.07 \\
(1,217.19)\end{array}$ & 0.62 & 0.28 \\
\hline Nonagricultural durables owned jointly & $\begin{array}{l}463.19 \\
(2,723.77)\end{array}$ & $\begin{array}{l}365.45 \\
(2,311.64)\end{array}$ & $\begin{array}{l}190.02 \\
(2,586.72)\end{array}$ & $\begin{array}{l}134.86 \\
(2,178.41)\end{array}$ & 0.07 & 0.01 \\
\hline
\end{tabular}

Source IFPRI impact evaluation of the strengthening the dairy value chain project: Baseline household survey in Bangladesh 2008 and endline survey 2012

a 1 acre $=100$ decimals. Descriptive statistics incorporate propensity weights; standard deviations in parentheses. Table does not report land owned by other household members, land owned jointly with nonmembers, or land that is rented out

milk sales to purchase cattle feed, medicine, artificial insemination services, and to seek treatment for cows with disease. Group savings are used to organize services such as deworming and vaccinations. Others report using their milk income to pay school fees. Women FGD participants reported that they had control over milk sales income and could manage it independently, although quantitative impact estimates suggest that the change in patterns in decisionmaking over milk income was not significant (Quisumbing et al. 2013).

Similar to the MSDDP, in the SDVC project area, participants reported increased labor demands linked to milk production. Using recommended feeding and care practices has resulted in an additional 15 to $45 \mathrm{~min}$ of work daily, depending on the number of dairy cattle owned. Project participants reported that nearly all of the labor increase is borne by women in the household; men's increased contribution is reported to be low because men spend only a few days a month tending cows, whereas women tend to them daily.

The impact evaluation found that dairy incomes and consumption by project participants did not increase significantly relative to a control group of dairy smallholders in the same locality who had access to chilling plants, but were not able to avail of project-related services such as training and access to milk collection centers (Quisumbing et al. 2013). SDVCP participation did not significantly change the number of livestock owned (cattle ownership in both treatment and control groups did not increase significantly between baseline and endline), although it slightly increased joint ownership by men and women of agricultural productive assets (increases in joint ownership of agricultural durables were significant in the treatment group but not the control group), indicating joint income diversification beyond dairy. Given that women owned far fewer assets than men prior to the project, this change reflects a small move toward gender equality. Decisionmaking regarding household expenditures and use of milk continued to be dominated by men, although women's voice in deciding about feed and inputs for cattle increased. Project participation also increased some dimensions of women's mobility, with women having a greater say regarding the locations to which they could travel independently (both related to the dairy value chain and otherwise).

Project impacts, however, were not limited to asset ownership. CARE's core programming in Bangladesh includes activities to empower women. The midterm evaluation of the SDVC project noted that the project's "group approach to capacity building has proven to be useful to building confidence of poor rural women and should be continued" (Alam et al. 2011, p. 35). Some adaptations, even if not intended to redress gender biases, also increased women's participation. Although most households sold milk within the village to either milkmen (who went door-to-door) or to the informal market at baseline (Ahmed et al. 2009), locating fixed milk collection facilities (including testing for quality using a lactometer) more conveniently within the village benefits all dairy producers because it reduces transactions and transportation costs and also ensures quality of the milk. By the time of the midterm evaluation, respondents perceived that the overall quantity and quality of milk had improved as a result of the project (Alam et al. 2011), and the endline evaluation revealed that norms regarding women's mobility had changed in terms of fewer objections to women's going to places where they could access value chain services (Quisumbing et al. 2013). The milk collection facilities within the village, however, do not directly reduce the barriers to women's mobility outside the village-chilling plants are typically located in larger market areas-but they offer a way to sell milk with lower transactions cost while assuring milk quality.

Attempts to increase women's participation throughout the dairy value chain in Bangladesh have not been uniformly effective. While SDVCP has done well with respect 
to women producers, with close to $80 \%$ of the project's producers being women, by 2009 , only $25 \%$ LHW and $17 \%$ of milk collectors were women (Alam et al. 2011). Rearing dairy cows within the homestead is a traditional, acceptable, and respectable task for women, but being a livestock health worker or collector is a nontraditional occupation. Cultural barriers to becoming a LHW appear to be less than those associated with being a milk collector. Women LHWs have been successful, and men also said that being a LHW is an honorable profession, and that a woman will be recognized for the money she earns and the service she delivers (Alam et al. 2011). LHWs who are women can more easily meet and talk with other women within their homesteads. The midterm evaluation (Alam et al. 2011) found that women reported feeling more comfortable talking to another woman than to a man about their dairy problems. And while women working as LHWs can serve as role models, concerns about physical security related to attending to late night calls, traveling great distances to attend to clients, fulfilling domestic responsibilities, and interacting with nonfamily members nonetheless remain barriers to increased involvement of women as LHWs.

Community members perceived that milk collection would be difficult for women because physical strength is required to drive bicycle-powered carts, collect and transport the milk containers, and because women would need to be away from their home for an extended period. To address these constraints, fixed milk collection points were set up at convenient locations within the village. Informal processors report that village-based collection points might be possible, since many women go to the market to sell milk anyway (Alam et al. 2011). Transporting milk to the chilling plant remains challenging. Not only is milk transportation physically difficult, but chilling plant staff also doubted that a woman could be swift in transactions and capable of increasing coverage on her own. While these misgivings may arise from real logistical challenges (distances, need for physical strength, numeracy), they reflect even more sharply the limitations created by cultural perceptions of women's roles.

Restrictions on women's mobility continue to challenge increased women's participation in the Bangladeshi context. Reluctance of husbands and older relatives of female farmer leaders and LHWs to permit them to attend residential training away from their homes was overcome by allowing them to observe the training and training venues. According to the project's gender manager, the project has successfully addressed most of the problems including a few incidents of domestic violence. Project implementers found that allowing male family members and guardians to observe project activities and participate in discussions was a good way to sensitize men toward the women in their family. With GAAP support, CARE also undertook a pilot community intervention to increase men's support for women's ownership and control of assets (including livestock), support women in their domestic responsibilities, and reduce domestic violence. This highlights the important lesson that projects, even if aiming to empower women, must also involve men and build support among them.

The SVDC project may have built on existing social capital, because dairy producer groups in Bangladesh are mostly, though not exclusively, composed of women. Women group members strategically choose members who are men (typically a husband of one of the members, who is literate and numerate) who can contribute new skills to the group. Some producer groups have used group savings to purchase dairy cows in the group's name, using social capital to catalyze the accumulation of livestock capital. Group-based approaches to service delivery are commonplace in Bangladesh; membership in both local and international NGOs tends to be pro-poor, and women are more likely to participate in these NGOs than men (Quisumbing 2009). The value of these widened social networks and their role in supporting women's participation in the milk value chains appears to have had a positive impact.

\section{Summary of dairy value chain projects}

Some similarities and differences between these two projects in Mozambique and Bangladesh are worth noting. First, both projects had an explicit commercial orientation, although only Land O'Lakes distributed cows to households. CARE focused on households that already had dairy cattle. Even if households in the MSDDP received cattle, there were still asset requirements for participation. To receive a dairy cow, households had to meet the land access requirements for maintaining the improved breed cow. Women and very poor households clearly faced barriers to participation in these projects, and given the distribution of asset ownership between men and women, women would be expected to face difficulties in benefiting from them. Recognizing the underlying gender inequalities in Bangladesh's patriarchal society, CARE explicitly focused on empowering women, while Land O'Lakes was initially gender blind and only began integrating gender issues during the course of the project. Nevertheless, a small group of women in Mozambique stated that women in households headed by men did on occasion own cows, even if the animals were registered in the man's name in the project's records, and that some women claimed joint ownership for the animals, regardless of household headship. Most respondents stated further that whose name the 
cow was registered under did not influence the management of the animal.

In Bangladesh, FGDs among project participants showed that, among the $12.4 \%$ of women FGD participants who owned cows at the start of the project, $2.3 \%$ of them now own additional cows. A few noted that they purchased cattle of their own from the proceeds of milk sales. ${ }^{9}$ Also, some groups have bought improved breed cattle for group members with their savings, and these cows are jointly owned by the group (Waithanji et al. 2012). This is consistent with the survey data showing significant amounts of joint ownership even if social norms dictate that cattle belong to men. The implication is that ownership, like many norms, is dynamic. Gender responsive projects should look for opportunities to reinforce tendencies to strengthen women's rights and avoid reinforcing norms that disadvantage women.

Both projects provided training in aspects of dairy cow management, which increased women's involvement and contributed to household income, self-esteem, and some absolute (though not relative) economic benefits for women. In Bangladesh, where women were already involved in dairy cow management, although it was less commercially oriented, all the participants said that their knowledge of better farm management increased and that they adopted improved practices. In Mozambique, working with cattle was a new activity for women. Training provided by the project enabled them to take on an important role within a joint household livelihood strategy. Similar to the case with asset ownership, these findings show that gender roles are also dynamic and that projects can influence perceptions about who does what work and who makes which decisions.

Progress in these areas seems to have come at the cost of increased women's labor input. While the costs may not be justified in terms of women's direct economic benefits, women themselves value the benefits for the household, especially in Mozambique, and the non-economic benefits (self-esteem, increased mobility). It will be important to follow up the projects to see whether the initial changes persist and grow. In both cases, projects initiated activities that were meant to further enhance women's roles in the dairy value chains. Changes in roles and control over assets are possible, and women may be willing to trade off additional labor burdens for such gains, but projects should not leave this to chance, but make deliberate efforts to support these dynamics and look for opportunities to sustain improvement.

\footnotetext{
9 These numbers differ from those in the quantitative impact evaluation because they are based on different samples.
}

Gender and asset dynamics in interventions promoting high value crops and livestock for improved nutrition: Burkina Faso and Uganda

In both Burkina Faso and Uganda, creation and formalization of value chains is occurring, although to different extents. In Burkina Faso, vegetables and fruits continue to be marketed in small quantities, typically through local markets. The 2010 baseline study showed that agriculture is the main livelihood of the study population, with sorghum, millet, and beans produced most often (Berhman et al. 2011). Households typically cultivate multiple plots, but constraints related to water availability for agriculture and inputs "limit the production potential of households and constrain both the food availability and dietary diversity of households" (Berhman et al. 2011, p. 30). In the villages selected in Gourma Province, men are generally responsible for buying and selling high value livestock like goats, and women are engaged in cultivation, harvesting, and preparing of food, collection of water and firewood, and care of children.

Initial asset requirements in the nutrition-oriented projects were lower than those in the dairy-oriented projects, even if they required having access to land for growing high value crops. In the Burkina Faso project, homestead plots were small, and HKI made explicit efforts to make land available for the community garden, provide drip irrigation, and to transfer small livestock to women. Tables 4 and 5 present descriptive statistics on the value of household and agricultural assets, including livestock and the area of cultivated land controlled by men and women from the baseline and endline surveys. ${ }^{10}$ Overall, men controlled a higher value of assets as compared to women at both baseline and endline in both treatment and control villages. Men owned about 135,00 CFA francs of total assets at baseline in the treatment group, compared to only 47,000 CFA francs for women; the control group reports similar gender disparities in asset ownership. In general, men controlled higher value agricultural assets compared to women, while women controlled higher values of household durables as compared to men. While there was a significant impact of the program on increasing the quantity of agricultural assets held by women (Dillon et al. 2012) and a decrease in the ratio of the value of agricultural assets held by men relative to women in treatment villages

\footnotetext{
${ }^{10}$ The baseline questionnaire collected information on men's and women's assets but did not have a category for joint ownership, based on the common phenomenon of "separate purses" in West African households. Subsequently, new research in West Africa has shown that there may be a small degree of joint asset ownership, up to $25 \%$ in Ghana (Deere et al. 2013). The endline questionnaire followed the same protocol for collecting male and female asset ownership, for comparability with the baseline.
} 
Table 4 Value of household durables and agricultural assets at household level and by sex, baseline and endline, by treatment status, Burkina Faso

\begin{tabular}{|c|c|c|c|c|c|c|}
\hline \multirow[t]{2}{*}{ Variable } & \multicolumn{2}{|l|}{ Baseline (2010) } & \multicolumn{2}{|l|}{ Endline (2012) } & \multicolumn{2}{|c|}{$\begin{array}{l}t \text {-test of difference of baseline } \\
\text { and endline means ( } p \text {-value) }\end{array}$} \\
\hline & Treatment $\mathrm{N}=1,025$ & Control $\mathrm{N}=733$ & Treatment $\mathrm{N}=884$ & Control $\mathrm{N}=597$ & Treatment & Control \\
\hline \multicolumn{7}{|c|}{ Household durables: value } \\
\hline Men & $\begin{array}{l}25,672 \\
(45,788)\end{array}$ & $\begin{array}{l}30,207 \\
(41,927)\end{array}$ & $\begin{array}{l}25,689 \\
(35,030)\end{array}$ & $\begin{array}{l}25,892 \\
(33,993)\end{array}$ & 0.91 & 0.20 \\
\hline Women & $\begin{array}{l}32,067 \\
(39,475)\end{array}$ & $\begin{array}{l}33,137 \\
(34,801)\end{array}$ & $\begin{array}{l}38,277 \\
(37,684)\end{array}$ & $\begin{array}{l}38,370 \\
(39,855)\end{array}$ & 0.00 & 0.00 \\
\hline Household & $\begin{array}{l}57,739 \\
(65,191)\end{array}$ & $\begin{array}{l}63,344 \\
(63,053)\end{array}$ & $\begin{array}{l}63,966 \\
(59,950)\end{array}$ & $\begin{array}{l}64,262 \\
(63,848)\end{array}$ & 0.02 & 0.26 \\
\hline \multicolumn{7}{|c|}{ Agricultural assets: value } \\
\hline Men & $\begin{array}{l}23,395 \\
(47,395)\end{array}$ & $\begin{array}{l}23,241^{\mathrm{a}} \\
(35,524)\end{array}$ & $\begin{array}{l}24,072 \\
(36,406)\end{array}$ & $\begin{array}{l}28,078 \\
(66,709)\end{array}$ & 0.84 & 0.16 \\
\hline Women & $\begin{array}{l}1,537 \\
(3,232)\end{array}$ & $\begin{array}{l}1,853^{\mathrm{a}} \\
(3,903)\end{array}$ & $\begin{array}{l}4,035 \\
(9,747)\end{array}$ & $\begin{array}{l}2,101 \\
(7,864)\end{array}$ & 0.00 & 0.31 \\
\hline Household & $\begin{array}{l}24,932 \\
(47,583)\end{array}$ & $\begin{array}{l}25,094^{\mathrm{a}} \\
(35,826)\end{array}$ & $\begin{array}{l}28,107 \\
(37,477)\end{array}$ & $\begin{array}{l}30,179 \\
(67,482)\end{array}$ & 0.26 & 0.12 \\
\hline \multicolumn{7}{|c|}{ Total assets: value } \\
\hline Men & $\begin{array}{l}135,171 \\
(204,070)\end{array}$ & $\begin{array}{l}136,995 \\
(168,998)\end{array}$ & $\begin{array}{l}142,843 \\
(209,021)\end{array}$ & $\begin{array}{l}151,839 \\
(223,254)\end{array}$ & 0.68 & 0.09 \\
\hline Women & $\begin{array}{l}47,468 \\
(68,765)\end{array}$ & $\begin{array}{l}50,196 \\
(47,648)\end{array}$ & $\begin{array}{l}59,797 \\
(64,305)\end{array}$ & $\begin{array}{l}56,395 \\
(52,884)\end{array}$ & 0.00 & 0.01 \\
\hline Household & $\begin{array}{l}182,639 \\
(227,503)\end{array}$ & $\begin{array}{l}187,191 \\
(190,946)\end{array}$ & $\begin{array}{l}202,640 \\
(232,384)\end{array}$ & $\begin{array}{l}208,234 \\
(250,287)\end{array}$ & 0.07 & 0.03 \\
\hline
\end{tabular}

Numbers are mean and standard deviations (in parentheses). All monetary values are reported in CFA francs, which are fixed to the Euro in a ratio of one euro $=655.957 \mathrm{CFA}$ francs or one $\mathrm{CFA}$ franc $=0.00152449$ euros

${ }^{a}$ Means $\mathrm{N}=732$

(15.2-6), compared to a slight increase in the ratio in control villages (van den Bold et al. 2013), there were no statistically significant program impacts on changes in durable, agricultural, or total asset values for either men or women. That is, even if there are significant differences between baseline and endline means of the value of women's agricultural assets and the total value of assets owned by women in the treatment group (Table 4), there were also significant changes in these variables for the control group, thus the net impact of the program on the value of women's assets was not significant. With regards to livestock, men held higher values of small animals and large livestock than women at both baseline and endline in both types of villages. At baseline, men's ownership of small animals and large livestock in treatment villages was valued at about 124,000 CFA francs and about 370,000 CFA francs, respectively, the corresponding values for women were much smaller-around 26,000 CFA francs worth of small animals and 6,000 CFA francs worth of large livestock. Although values of livestock owned were larger in the control group, the gender disparities between men's and women's livestock ownership exist. While program impacts on small animal ownership were positive and statistically significant for both men and women in intervention villages, with a differential increase larger for men than for women (not shown), impacts on large livestock or the value of small animals were not significant. That is, even if the value of small animals significantly increased for both women and men in the treatment villages between baseline and endline (Table 5), this also increased in control villages, resulting in an insignificant program impact. Men, on average, also cultivated larger land areas as compared to women at baseline and endline in both control and intervention villages-around three hectares for men, compared to a little over one hectare for women, on average (Table 5).

Qualitative research revealed that in 2011, $95 \%$ of beneficiary women believed themselves to be the owners of their gardens, even though only one woman ( $2 \%$ ) claimed to own the land on which the garden was planted. Land for 
Table 5 Land cultivated and value of livestock holdings, baseline and endline, by treatment status and by sex, Burkina Faso

\begin{tabular}{|c|c|c|c|c|c|c|}
\hline & \multicolumn{2}{|l|}{ Baseline (2010) } & \multicolumn{2}{|l|}{ Endline (2012) } & \multicolumn{2}{|c|}{$\begin{array}{l}t \text {-test of difference of baseline } \\
\text { and endline means ( } p \text {-value) }\end{array}$} \\
\hline & Treatment $\mathrm{N}=1,025$ & Control $\mathrm{N}=738$ & Treatment $\mathrm{N}=730$ & Control $\mathrm{N}=418$ & Treatment & Control \\
\hline \multicolumn{7}{|l|}{ Land cultivated } \\
\hline Men (hectares) & $\begin{array}{l}\mathrm{N}=920 \\
3.2 \\
(3.1)\end{array}$ & $\begin{array}{l}\mathrm{N}=679 \\
3.1 \\
(2.8)\end{array}$ & $\begin{array}{l}\mathrm{N}=768 \\
3.1 \\
(3.9)\end{array}$ & $\begin{array}{l}\mathrm{N}=527 \\
2.8 \\
(1.9)\end{array}$ & 0.49 & 0.00 \\
\hline Women (hectares) & $\begin{array}{l}\mathrm{N}=718 \\
1.4 \\
(5.4)\end{array}$ & $\begin{array}{l}\mathrm{N}=511 \\
1.2 \\
(1.8)\end{array}$ & $\begin{array}{l}\mathrm{N}=760 \\
0.8 \\
(1.7)\end{array}$ & $\begin{array}{l}\mathrm{N}=348 \\
1.6 \\
(8.2)\end{array}$ & 0.03 & 0.73 \\
\hline \multicolumn{7}{|c|}{ Small animals: value } \\
\hline Men & $\begin{array}{l}123,617 \\
(157,316)\end{array}$ & $\begin{array}{l}139,499 \\
(166,398)\end{array}$ & $\begin{array}{l}212,365 \\
(262,249)\end{array}$ & $\begin{array}{l}212,309 \\
(262,952)\end{array}$ & 0.00 & 0.00 \\
\hline Women & $\begin{array}{l}26,319 \\
(48,251)\end{array}$ & $\begin{array}{l}29,034 \\
(49,906)\end{array}$ & $\begin{array}{l}55,011 \\
(74,706)\end{array}$ & $\begin{array}{l}56,181 \\
(76,944)\end{array}$ & 0.00 & 0.00 \\
\hline Household & $\begin{array}{l}149,936 \\
(178,585)\end{array}$ & $\begin{array}{l}168,533 \\
(185,702)\end{array}$ & $\begin{array}{l}267,376 \\
(294,981)\end{array}$ & $\begin{array}{l}268,489 \\
(295,315)\end{array}$ & 0.00 & 0.00 \\
\hline \multicolumn{7}{|c|}{ Large livestock: value } \\
\hline Men & $\begin{array}{l}370,695 \\
(495,489)\end{array}$ & $\begin{array}{l}425,789 \\
(512,365)\end{array}$ & $\begin{array}{l}816,751 \\
(1,283,962)\end{array}$ & $\begin{array}{l}752,053 \\
(1,049,704)\end{array}$ & 0.00 & 0.00 \\
\hline Women & $\begin{array}{l}6,463 \\
(52,024)\end{array}$ & $\begin{array}{l}12,444 \\
(71,783)\end{array}$ & $\begin{array}{l}5,916 \\
(42,398)\end{array}$ & $\begin{array}{l}7,917 \\
(54,489)\end{array}$ & 0.42 & 0.24 \\
\hline Household & $\begin{array}{l}377,158 \\
(506,448)\end{array}$ & $\begin{array}{l}438,234 \\
(528,404)\end{array}$ & $\begin{array}{l}822,667 \\
(1,290,597)\end{array}$ & $\begin{array}{l}759,970 \\
(1,056,992)\end{array}$ & 0.00 & 0.00 \\
\hline
\end{tabular}

Numbers (for small animals and large livestock) are N, mean and standard deviation (in parentheses). Numbers for land are hectares, mean and standard deviations (in parentheses). All monetary values are reported in CFA francs, which are fixed to the Euro in a ratio of 1 euro $=655.957$ CFA francs or $1 \mathrm{CFA}$ franc $=0.00152449$ euros

gardens was primarily reported to be owned by husbands (44\%), another village member $(28 \%)$, or another male household member (21\%), but by 2012, $64 \%$ of beneficiary women reported that land for gardens was owned by husbands, and the proportion of women who reportedly owned land had increased to $10 \%$, possibly due to an overall increase in household landownership. Beneficiary women also reported that they were primarily responsible for taking care of the garden in both 2011 and 2012 (84 and $87 \%$, respectively).

Decisionmaking on produce by beneficiary women increased from 75 to $92 \%$ between 2011 and 2012, while decisionmaking by men on produce decreased from 9 to $0 \%$ in the same period. A similar change occurred for the management of revenue from the sale of produce. With regards to decisionmaking over chickens, in both 2011 and 2012 a higher proportion of beneficiary women than men were allowed to sell chickens and make decisions on chickens, respectively, while a reverse pattern was evident in control villages, and beneficiary women experienced an increased likelihood of keeping income from the sale of chickens as compared to men in intervention villages. However, ownership and decisionmaking authority related to goats remained primarily in the hands of men. In addition to the positive findings related to control over vegetables and chickens, after 2 years of program implementation, a higher proportion of both male and female respondents in intervention compared to control villages held positive attitudes regarding women's land rights and believed that women could be capable farmers (van den Bold et al. 2013). After 1 year of HKI program implementation, process evaluation findings (Olney et al. 2013) showed that beneficiary women reported an increase in their knowledge of poultry production and new gardening techniques, enabling them to grow vegetables in their gardens year round. Ninety percent of these women beneficiaries reported to have established new gardens since the start of the program. Further, women believed that their increased production improved their own and their families' health. Approximately half of beneficiaries specifically stated that they learned about the importance of immediate breastfeeding (53\%), exclusive breastfeeding for the first 6 months of life (48\%), and 
practices related to complementary feeding ( $71 \%)$. Beneficiaries were more conversant on topics covered in the trainings than non-beneficiaries, including those related to the optimal timing for the introduction of breastfeeding and complementary feeding, micronutrient-rich foods that could be used to enrich porridge for young children, as well as identification of vitamin-A rich foods. In addition, the majority of beneficiaries interviewed $(93 \%)$ believed the nutrition trainings contributed to gaining new knowledge ( $29 \%$ ); adoption of better practices; enabling them to take better care of their children (32\%); improving the nutrition of themselves and their children (29\%); and protecting their children against common illnesses (16\%) (Olney et al. 2013).

In Uganda, the value chain in potatoes, primarily white potatoes with a smaller proportion of red potatoes, is still rudimentary and local. Sweet potatoes, although an important staple, are not a significant portion of the marketed production (Wang'ombe 2008). Women have primary control over food choices, while both men and women have complex and shifting roles concerning crop choice and on-farm labor supply in smallholder agriculture. The REU project was implemented in three districts in Uganda, two of which (Kamuli and Mukono) had more female involvement in agricultural decisionmaking, with the other (Bukedea) having greater male control over agriculture. Both men and women said that in their capacity as household heads, men have the final say on crop type and quantity for a given plot. Yet in practice, participants reported that decisions are commonly made after consultation between husbands and wives. Women reported that the only exception is that women are solely in charge of decisions about which and how much of a crop to grow on plots controlled and managed by women, while men reported that they have decisionmaking authority even over such plots (Berhman 2011).

Similar complexity surrounds the responsibility for marketing the sweet potato vines. Respondents from Kamuli, both men and women, reported that men are responsible for vine sales because they are the household head and are responsible for finances. On the other hand, in Bukedea, men and women concurred that it is the women who take OSP to the market, because sweet potato is locally described as a "women's crop" (Berhman 2011).

Table 6 shows that, similar to the other case studies, land is owned mostly by husbands in the REU project sites. At baseline, men owned 1.94 acres in treatment households and 1.86 in control households; this did not change significantly at endline. In contrast, wives had 0.12 acres in treatment households and 0.13 acres in control households at baseline; increases at endline were not statistically significant. Wives also own a very low share of household nonland assets, although they can access a larger share of assets through joint ownership with the head.

We further examine the distribution of the household's nonland assets. Consumer durables accounted for over three-quarters of nonland assets value in 2007 (Table 6). Of these, the majority were owned by the husband and about $30 \%$ owned jointly by both spouses. Agricultural durables accounted for a meager share of total nonland assets. Husbands owned close to $50 \%$ of these and wives about $12 \%$. Jewelry constituted less than a percent of total nonland asset value. Wives owned one-fifth of the household jewelry but the husbands still owned the majority. Livestock constituted of a fifth of the value of total nonland assets and while wives owned a quarter of total livestock value, it is still half the share owned by husbands.

Table 7 shows that, at baseline, women had exclusive control of only $16 \%$ of landholdings and $22 \%$ of other assets. Respondents reported that $25 \%$ of land and $31 \%$ of nonland assets were jointly owned by men and women. There is considerable variation by district, with a clear pattern of much higher share of land $(59 \%)$ and nonland assets $(62 \%)$ under exclusive control by men in Bukedea.

In Uganda, gendered differences in landownership have important impacts on decisionmaking in agriculture. The probability of adoption of OSP is highest on parcels for which there is joint control, but where women take the lead in deciding which crops are grown, possibly because extension messages about the nutritional value of OSP were targeted to women. The probability of adopting OSP is also lowest on parcels exclusively controlled by men (Gilligan et al. 2014). Figure 2 shows the response to the question, "Who decided what to grow on this parcel?" in the first season of 2009. The figure shows that on nearly $60 \%$ of parcels, control over crop choice is joint, but that the men take the lead in making the decision. However, on $20 \%$ of parcels, women solely make decisions on crop choice, reflecting in part the number of single-headed households headed by women. Only $4.5 \%$ of parcels are reported to be under exclusive male control, while the remaining $16.5 \%$ of parcels are under joint control with a woman taking the lead in the decisionmaking. The figure also shows that in Bukedea, the pattern of male dominance of control over crop choice decisions is magnified.

Another challenge faced by projects was the role of targeting and extension services, especially in the case of nontraditional crops like OSP. Biofortification strategies have to be adapted to local context since adoption will vary considerably by crop and location in terms of delivery strategies, crop traits, quality of existing systems for accessing seeds or planting material, the role of marketing 
Table 6 Asset ownership by gender in Uganda, baseline and endline, by treatment status $(\mathrm{N}=1,594)$

\begin{tabular}{|c|c|c|c|c|c|c|}
\hline & \multicolumn{2}{|c|}{ Baseline (2007) } & \multicolumn{2}{|c|}{ Endline (2009) } & \multicolumn{2}{|c|}{$\begin{array}{l}t \text {-test of difference of baseline } \\
\text { and endline means ( } p \text {-value) }\end{array}$} \\
\hline & Treatment & Control & Treatment & Control & Treatment & Control \\
\hline \multicolumn{7}{|l|}{ Land owned (acres) } \\
\hline Land owned by husband & $\begin{array}{l}1.94 \\
(3.72)\end{array}$ & $\begin{array}{l}1.86 \\
(4.36)\end{array}$ & $\begin{array}{l}1.96 \\
(2.62)\end{array}$ & $\begin{array}{l}1.67 \\
(2.42)\end{array}$ & 0.27 & 0.99 \\
\hline Land owned by wife & $\begin{array}{l}0.12 \\
(0.57)\end{array}$ & $\begin{array}{l}0.13 \\
(0.52)\end{array}$ & $\begin{array}{l}0.18 \\
(0.99)\end{array}$ & $\begin{array}{l}0.17 \\
(0.62)\end{array}$ & 0.09 & 0.18 \\
\hline Land owned jointly & $\begin{array}{l}0.83 \\
(5.77)\end{array}$ & $\begin{array}{l}0.61 \\
(1.95)\end{array}$ & $\begin{array}{l}0.80 \\
(2.48)\end{array}$ & $\begin{array}{l}0.67 \\
(2.44)\end{array}$ & 0.86 & 0.96 \\
\hline \multicolumn{7}{|c|}{ Nonland asset holdings (in thousand Ugandan shillings as of 2007) } \\
\hline Nonland assets owned by husband & $\begin{array}{l}1,544.90 \\
(5,469.51)\end{array}$ & $\begin{array}{l}1,510.57 \\
(6,742.47)\end{array}$ & $\begin{array}{l}2,150.38 \\
(6,182.85)\end{array}$ & $\begin{array}{l}1,717.82 \\
3,943.17)\end{array}$ & 0.30 & 0.00 \\
\hline Nonland assets owned by wife & $\begin{array}{l}172.89 \\
(538.75)\end{array}$ & $\begin{array}{l}199.04 \\
(634.09)\end{array}$ & $\begin{array}{l}349.39 \\
(1,319.27)\end{array}$ & $\begin{array}{l}343.08 \\
(819.23)\end{array}$ & 0.00 & 0.00 \\
\hline Nonland assets owned jointly & $\begin{array}{l}597.89 \\
(1,587.36)\end{array}$ & $\begin{array}{l}582.73 \\
(1,787.28)\end{array}$ & $\begin{array}{l}1,107.51 \\
(4,111.43)\end{array}$ & $\begin{array}{l}852.48 \\
(3,332.91)\end{array}$ & 0.02 & 0.00 \\
\hline \multicolumn{7}{|l|}{ Share of household nonland asset holdings } \\
\hline Consumer durables & $\begin{array}{l}0.76 \\
(0.23)\end{array}$ & $\begin{array}{l}0.77 \\
(0.22)\end{array}$ & $\begin{array}{l}0.76 \\
(0.21)\end{array}$ & $\begin{array}{l}0.77 \\
(0.22)\end{array}$ & 0.73 & 0.91 \\
\hline Agricultural durables & $\begin{array}{l}0.04 \\
(0.08)\end{array}$ & $\begin{array}{l}0.04 \\
(0.10)\end{array}$ & $\begin{array}{l}0.03 \\
(0.08)\end{array}$ & $\begin{array}{l}0.03 \\
(0.08)\end{array}$ & 0.36 & 0.13 \\
\hline Jewelry & $\begin{array}{l}0.00 \\
(0.01)\end{array}$ & $\begin{array}{l}0.00 \\
(0.01)\end{array}$ & $\begin{array}{l}0.00 \\
(0.01)\end{array}$ & $\begin{array}{l}0.00 \\
(0.00)\end{array}$ & 0.00 & 0.14 \\
\hline Livestock & $\begin{array}{l}0.20 \\
(0.22)\end{array}$ & $\begin{array}{l}0.19 \\
(0.20)\end{array}$ & $\begin{array}{l}0.21 \\
(0.20)\end{array}$ & $\begin{array}{l}0.19 \\
(0.21)\end{array}$ & 0.84 & 0.35 \\
\hline \multicolumn{7}{|l|}{ Proportions of nonland asset categories } \\
\hline Consumer durables owned by husband & $\begin{array}{l}0.60 \\
(0.40)\end{array}$ & $\begin{array}{l}0.58 \\
(0.40)\end{array}$ & $\begin{array}{l}0.59 \\
(0.40)\end{array}$ & $\begin{array}{l}0.60 \\
(0.39)\end{array}$ & 0.00 & 0.12 \\
\hline Consumer durables owned by wife & $\begin{array}{l}0.11 \\
(0.25)\end{array}$ & $\begin{array}{l}0.12 \\
(0.27)\end{array}$ & $\begin{array}{l}0.12 \\
(0.26)\end{array}$ & $\begin{array}{l}0.12 \\
(0.26)\end{array}$ & 0.08 & 0.63 \\
\hline Consumption durables owned jointly & $\begin{array}{l}0.30 \\
(0.46)\end{array}$ & $\begin{array}{l}0.30 \\
(0.46)\end{array}$ & $\begin{array}{l}0.33 \\
(0.46)\end{array}$ & $\begin{array}{l}0.24 \\
(0.42)\end{array}$ & 0.00 & 0.19 \\
\hline Agricultural durables owned by husband & $\begin{array}{l}0.47 \\
(0.46)\end{array}$ & $\begin{array}{l}0.47 \\
(0.46)\end{array}$ & $\begin{array}{l}0.50 \\
(0.46)\end{array}$ & $\begin{array}{l}0.50 \\
(0.46)\end{array}$ & 0.00 & 0.04 \\
\hline Agricultural durables owned by wife & $\begin{array}{l}0.11 \\
(0.25)\end{array}$ & $\begin{array}{l}0.12 \\
(0.27)\end{array}$ & $\begin{array}{l}0.12 \\
(0.26)\end{array}$ & $\begin{array}{l}0.12 \\
(0.26)\end{array}$ & 0.01 & 0.22 \\
\hline Agricultural durables owned jointly & $\begin{array}{l}0.42 \\
(0.49)\end{array}$ & $\begin{array}{l}0.41 \\
(0.49)\end{array}$ & $\begin{array}{l}0.38 \\
(0.48)\end{array}$ & $\begin{array}{l}0.38 \\
(0.48)\end{array}$ & 0.00 & 0.01 \\
\hline Jewelry owned by husband & $\begin{array}{l}0.51 \\
(0.48)\end{array}$ & $\begin{array}{l}0.48 \\
(0.47)\end{array}$ & $\begin{array}{l}0.49 \\
(0.47)\end{array}$ & $\begin{array}{l}0.54 \\
(0.46)\end{array}$ & 0.06 & 0.52 \\
\hline Jewelry owned by wife & $\begin{array}{l}0.19 \\
(0.36)\end{array}$ & $\begin{array}{l}0.21 \\
(0.38)\end{array}$ & $\begin{array}{l}0.18 \\
(0.34)\end{array}$ & $\begin{array}{l}0.22 \\
(0.36)\end{array}$ & 0.20 & 0.14 \\
\hline Jewelry owned jointly & $\begin{array}{l}0.30 \\
(0.46)\end{array}$ & $\begin{array}{l}0.30 \\
(0.46)\end{array}$ & $\begin{array}{l}0.33 \\
(0.46)\end{array}$ & $\begin{array}{l}0.24 \\
(0.42)\end{array}$ & 0.50 & 0.60 \\
\hline Livestock owned by husband & $\begin{array}{l}0.51 \\
(0.44)\end{array}$ & $\begin{array}{l}0.49 \\
(0.43)\end{array}$ & $\begin{array}{l}0.51 \\
(0.43)\end{array}$ & $\begin{array}{l}0.50 \\
(0.43)\end{array}$ & 0.48 & 0.97 \\
\hline Livestock owned by wife & $\begin{array}{l}0.24 \\
(0.35)\end{array}$ & $\begin{array}{l}0.25 \\
(0.35)\end{array}$ & $\begin{array}{l}0.24 \\
(0.34)\end{array}$ & $\begin{array}{l}0.26 \\
(0.36)\end{array}$ & 0.33 & 0.64 \\
\hline
\end{tabular}


Table 6 continued

\begin{tabular}{|c|c|c|c|c|c|c|}
\hline & \multicolumn{2}{|c|}{ Baseline (2007) } & \multicolumn{2}{|c|}{ Endline (2009) } & \multicolumn{2}{|c|}{$\begin{array}{l}t \text {-test of difference of baseline } \\
\text { and endline means ( } p \text {-value) }\end{array}$} \\
\hline & Treatment & Control & Treatment & Control & Treatment & Control \\
\hline Livestock owned jointly & $\begin{array}{l}0.25 \\
(0.42)\end{array}$ & $\begin{array}{l}0.26 \\
(0.42)\end{array}$ & $\begin{array}{l}0.26 \\
(0.42)\end{array}$ & $\begin{array}{l}0.25 \\
(0.42)\end{array}$ & 0.79 & 0.68 \\
\hline
\end{tabular}

Source HarvestPlus reaching end users orange-fleshed sweet potato baseline household survey, 2007 and 2009

Table 7 Baseline distribution of land and asset ownership, by gender and by site, Uganda $2007(\mathrm{~N}=1,594)$

Source Gilligan et al. (2014)

Descriptive statistics are presented for the pooled sample of treatment and control households

\begin{tabular}{llll}
\hline & Owned by husband & Owned by wife & Jointly owned \\
\hline Share of value of land owned & 0.59 & 0.16 & 0.25 \\
Share of value of nonland assets owned & 0.49 & 0.22 & 0.31 \\
Share of value of land owned, by district & & & \\
Kamuli & 0.46 & 0.20 & 0.35 \\
Bukedea & 0.74 & 0.11 & 0.15 \\
Mukono & 0.55 & 0.18 & 0.27 \\
Share of value of nonland assets owned, by district & & \\
Kamuli & 0.40 & 0.21 & 0.40 \\
Bukedea & 0.62 & 0.16 & 0.23 \\
Mukono & 0.42 & 0.28 & 0.32
\end{tabular}

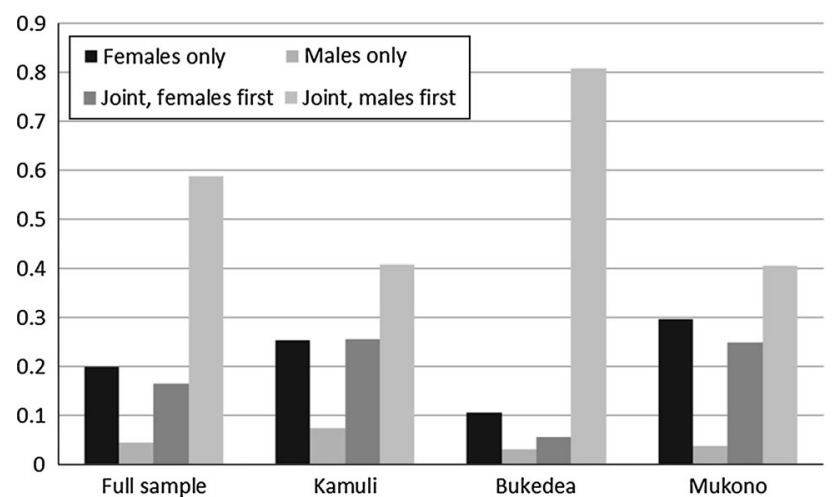

Fig. 2 The distribution of control over crop choice decisions on household parcels (proportion reporting), HarvestPlus Reaching End Users (REU) project, Uganda, 2009. Source Gilligan et al. (2014)

(Gilligan 2012), as well as gender norms. This contrasts with supplementation and fortification approaches, which have fairly uniform delivery mechanisms. Even among biofortification dissemination strategies, OSP is challenging. For many seed crops, adoption can be encouraged through marketing campaigns for biofortified seeds, but for crops like cassava and sweet potato, planting material in the form of vine cuttings cannot be stored in the same ways, making marketing ineffective as a primary dissemination strategy. Instead, most households obtain planting material from other households.
The use of women's groups for dissemination of OSP vines builds on social capital —an important (but often overlooked) asset that was instrumental in enabling women to adopt. Future efforts to disseminate OSP should continue to take the gendered nature of social networks into account. Although other types of sweet potato are traded commercially in the REU project districts, most households will initially obtain OSP through production for home consumption on their own land, and diffusion through social networks. In Kamuli and Munoko, only 16 and $15 \%$ of gifts and sales were to men, suggesting that OSP is largely viewed as a woman's crop. In Bukedea, $42 \%$ of gifts and sales were to men, indicating substantial gender differences in diffusion across districts.

The OSP impact evaluation (de Brauw et al. 2010) found that intakes of vitamin A significantly increased among all groups (children aged 6-35 months, children 3-5 years, and women), which was almost entirely attributed to increases in OSP consumption. A later study (Hotz et al. 2012) similarly found a substantial increase in total vitamin A intake from beta-carotene in all three age groups. They also found a positive association between vitamin A intake from OSP and vitamin A status at followup for children with low serum retinol at baseline, and there was a positive intervention impact on vitamin A status among children with complete data on key control 
variables (Hotz et al. 2012). The REU intervention also had significant positive impacts on several outcomes related to mother's knowledge about breastfeeding and correct childfeeding practices, and on their knowledge about vitamin A, despite the fact that mothers in Uganda already had a high level of knowledge about several child feeding practices and vitamin $\mathrm{A}$ at baseline.

The evaluation of the REU project found no evidence of impact on fathers' knowledge of child feeding practices in Uganda (de Brauw et al. 2010), and the contribution of nutrition messages received by women on the impact of the project on OSP adoption and dietary intakes of vitamin A appears to be relatively small (de Brauw et al. 2010). Nonetheless, in this setting, our results suggest that engagement of the project with both men and women in the household may be the best strategy to promote adoption.

\section{Summary of nutrition-oriented projects}

In both Uganda and Burkina Faso, the primary goal of the projects was improved nutrition, with income generation as a secondary objective. This was reflected in project design and implementation, resulting in positive impacts on nutrition (de Brauw et al. 2010; Dillon et al. 2012). They were based on an understanding of agriculture-gendernutrition linkages and included nutrition and health components in addition to agricultural activities.

Agricultural interventions using similar modalities (such as homestead food production) also need to be adapted to the local context to be effective, as illustrated by the HKI project. HKI originally piloted the HFP model in Bangladesh in the 1980s, expanded and adapted the program for Cambodia, Nepal, and the Philippines in the late 1990s, and recently adapted it for West African conditions. The model was broadened to include small animal husbandry in order to address multiple micronutrient deficiencies, including iron and zinc. The original Bangladesh model did not initially challenge gender norms or patriarchal power structures (Hillenbrand 2010). Agricultural training was conducted by all-male field staff, while nutrition education was delivered by all-female staff. The main selection criteria for the VMF owner were possession of a suitable and sizeable land plot and prior experience in farming, favoring men for VMF selection. Inadvertently or deliberately, men were not held responsible for the nutritional side of food production, reinforcing existing gender roles. Agricultural technology transfer in this model reinforced the stereotypes that men are capable of "farming," while women are suited for "gardening" and food preparation.

Although HFP has been viewed as "empowering" to women, the notion of empowerment was initially not central or even tangential to the programming. The language of "women's empowerment" gradually crept into the documentation, as field officers observed positive changes in women's quality of life and greater decisionmaking power within the household (Hillenbrand 2010, p. 416). Subsequently, programming in Bangladesh was modified to address gender concerns more directly, by eliminating land size as a criterion for choosing VMF owners, having women's groups themselves choose the VFL, using group-based marketing, using new tools to describe and build women's own capacities and needs, and creating opportunities at all levels for staff training and reflection on gender. Many of these changes have been included in the design of HKI's current HFP programs, including the one in Burkina Faso.

HKI's willingness to adapt program design to local gender norms is evident in the Burkina Faso intervention. Specific adaptations were made for Burkina Faso, where the VFLs are women, and model farms are being cultivated on land that is designated by the village for that purpose. The Burkina Faso environment, similar to much of West Africa, faces more severe water constraints than HKI's Asian sites, and the process evaluation also identified potential program adaptations related to irrigation. Even if both men and women would benefit from adaptations addressing water scarcity, women may gain greater benefits because they are typically responsible for water collection. In addition, increasing space available at VMF would tend to benefit women more, as they typically do not have land of their own that has a reliable water supply (Olney et al. 2013).

Given that the focus on reaching undernourished women and children, both the OSP and HKI projects targeted poor households and provided them with inputs and, in the case of HKI, with livestock assets. In both cases, care was taken to target women as beneficiaries, to involve them in the projects and to transfer assets to them. Although the women did not always retain control of all of the assets, they did control those assets essential to project success, even increasing their span of control in some cases (as in the HKI project). Although access to land was required in order to take up the activities promoted by the projects, "ownership" (as opposed to access) was not explicitly required. In the case of $\mathrm{HKI}$, the project worked to improve women's access during the course of the project, and to change gender norms about women's ability to own land, as well as address the specific local constraint of water scarcity by providing drip irrigation. Land tenure arrangements are especially complicated in Africa, where there may be multiple owners of land within the household, and ownership of a plot of land does not necessarily mean primary decisionmaking power on, or actual cultivation of, that plot. If project designers take asset requirements into account and attempt to relieve asset requirement constraints when targeting poorer women, they can improve 
project impact, and potentially also contribute to longerterm changes in women's empowerment.

Similar to the livestock projects, the increased demands on women's time were an issue identified by the HKI process evaluation. Although the women were generally enthusiastic about the E-HFP program and its benefits, and all but one said that they planned to continue participating in the program, about half reported having to make sacrifices in other areas. Out of 55 women who participated in the qualitative research, $26 \%$ stated that time spent maintaining gardens conflicted with other activities, such as domestic household chores, cooking, working outside of the home, commerce, childcare, and collecting wood. Time spent taking care of chickens, on the other hand, only affected $7 \%$ of these beneficiaries. This was likely due both to the fact that less time is needed to care for chickens on a day-to-day basis as well as the fact that their husbands were more likely to be the primary person responsible for this task (Olney et al. 2013).

Neither nutrition-oriented project examined the control of income from the newly introduced high value crops, because their primary focus was increasing production for home consumption. In addition, neither project targeted nutritional knowledge to men. Whether expansion of market-oriented production will result in women's loss of control of income derived from these high-value cropsand possible dilution of nutritional gains-will need to be monitored. It is possible that, if new crop varieties are introduced together with a deliberate effort to empower women, women can avoid being marginalized if further market development occurs. If men were also included in nutrition sensitization, they may also be more inclined to safeguard nutritional gains, even as production for the market increases.

\section{Conclusions: emerging implications for promoting high-value commodities and value chain development}

Based on case studies of four agricultural development projects, this paper aimed to investigate (1) how initial asset endowments of men and women affect their ability to participate in and benefit from agricultural development projects that promote high value crops and livestock; (2) how these interventions affected men's and women's abilities to benefit from project interventions, including their ability to accumulate assets; and (3) what these results imply for the promotion of market-oriented agriculture and value chain development.

Emerging findings from the qualitative studies and the quantitative impact evaluations of these four projects reveal a complex relationship between the promotion of high-value commodities in the context of promoting market-oriented agriculture, improving health and nutrition, and the gendered use, control, and ownership of different types of assets.

First, projects promoting the production of high value commodities need assets. The asset requirements may be particularly important in commercially-oriented projects, which typically include them for the sake of "project sustainability." However, while households may have these assets, their ownership is not equally distributed between men and women within households. Not all project designers recognize and appreciate the significance of different individual rights over assets within the same household. Gendered use, control, and ownership of assets affect who within the household can participate in agricultural development projects, and how household members benefit from participation. When men own the assets, they are likely to capture the majority of the benefitsunless project designers make a deliberate effort to change the distribution of benefits.

Nutrition-oriented projects also require some minimum stock of assets, however, because of their nutrition objective, they tend to do a better job of recognizing the pathways that link agriculture, gender, and nutrition, and use this knowledge to design interventions that target and benefit women. Lessons can be learned from the nutritionoriented projects on how to integrate gender issues and empower women, even in other types of projects. Moreover, in most of the contexts in which these agricultural development programs operate, avoiding harm to nutrition is important, so this framework may be useful.

Second, agricultural development projects can affect men's and women's use, control, and ownership of assets. Many projects (especially as originally designed) tended to reinforce social norms related to asset ownership and control of income from the assets. However, there were examples of dynamism in gender norms related to assets and to roles and responsibilities. Projects need to be aware of these and to support opportunities to increase equity rather than inadvertently promote the patriarchal status quo. Having an explicit gender strategy might help project designers and implementers be more aware of the potential impacts of projects on gendered asset use, control, and ownership.

Being aware of project impacts also means paying attention not only to tangible assets, which are easier to measure, but also intangible ones like human and social capital. Each of these studies speaks to the critical role of human and social capital, through training programs and the formation and management of different types of farmer associations, which may facilitate the accumulation of other types of assets. Because the social and cultural constraints to women's participation in these projects differ across these countries and contexts, local adaptations need to be made for these projects to succeed, such as disseminating extension messages through farmers' groups and 
women's networks in Uganda, and reducing constraints to women's mobility in Bangladesh.

What does this mean for projects promoting high-value agriculture and value chains? For projects to encourage, build on, and support changes in gender norms, having an explicit asset focus may facilitate this process, because gendered asset ownership and control are measurable indicators of gender norms that can be feasibly incorporated into project monitoring and evaluation systems. Using gender-asset indicators to evaluate project impact requires both a good understanding of the local context and good monitoring systems that are sensitive to what is happening in the project. This highlights the importance of qualitative research and process evaluation, not simply the mechanical collection of quantitative indicators. Projects also generate different types of benefits-household and individual, economic and non-economic - and often, there are trade-offs among them. When assessing impacts, these trade-offs need to be considered to understand whether women's net benefits are positive or negative. This suggests that a multidimensional indicator, similar to the Women's Empowerment in Agriculture Index (WEAI) (Alkire et al. 2013) that is being used in the US Feed the Future Initiative, may be useful to a wide range of agricultural development projects. ${ }^{11}$

Training and facilitating the return of benefits to the women who are producers and suppliers are among the basic principles for gender-equitable efforts to promote market-oriented agriculture, whether in support of nutrition-related objectives or value chain development. However, while increases in financial, human, and social capital are clearly an important first step, other targeted support to the farmers' groups may be needed to enable women to acquire other physical assets in order to fully benefit from the increased market orientation, to expand agribusinesses, and to enter the higher value nodes of the value chain, such as processing and export.

One strategy may be to strengthen horizontal linkages between different producer associations, cooperatives, and business associations, particularly those at the same node of the value chain. The formation of the groups and the subsequent creation of links between them help overcome constraints that individual famers may face to meet large orders or to purchase inputs. Producer organizations' members can often access more services from other actors in the value chain, including inputs, credit, and education or training. Having the backing of the group can increase incentives to buyers and producers to engage in market

\footnotetext{
11 The development of the WEAI was itself influenced by the development of gender and assets indicators in GAAP, because decisionmaking over production, resources (including land and assets), and community leadership (social capital) are three of the five WEAI domains.
}

relationships. Additional adaptations may also be needed to make each intervention successful in its local context. While taking existing gender norms into account is important, adapting to existing norms runs the risk of reinforcing them, rather than using the project as an opportunity to be gender-transformative or to engage men to support the project. Similar to other development interventions, gender-sensitive efforts to encourage market-oriented agriculture that also attempt to build women's assets, reduce gender asset inequality, and meet nutrition objectives must balance the need to meet women's practical versus strategic gender needs. Finding ways to facilitate and sustain women's control of the physical and financial assets generated by their increased involvement in market-oriented agriculture, while not compromising their own and their families' health and nutrition, remains an important challenge that needs to be addressed by these and future gender-sensitive high-value agriculture projects.

Acknowledgments This paper was developed for the UN Foundation and ExxonMobil Foundation research collaboration on "Building a Roadmap for Women's Economic Empowerment," building on the Gender, Agriculture, and Assets Project (GAAP), supported by the Bill $\&$ Melinda Gates Foundation. We would like to thank Mayra Buvinic and Emily Courey Pryor for their guidance to the overall project, Elena Bardasi for insightful comments, and participants at a workshop at Greentree Estate for helpful discussions. We also would like to acknowledge the contributions from our research collaborators and partners including Andrew Dillon, Pauline Muindi, Jemimah Njuki, Amber Peterman, Wahid Quabili, Esteban Quiñones, Martha Rogers, and Shalini Roy. We also thank Jay Willis and Ginette Mignot for help with formatting the paper. All errors and omissions are ours.

\section{References}

Ahmed, A.U., B. Minten, A.R. Quisumbing, D. Roy, M. Khondkar, A.M. Muzareba, and Data Analysis and Technical Assistance Limited. 2009. Evaluating the dairy value chain project in Bangladesh: Baseline report. Washington, DC: International Food Policy Research Institute.

Alam, A., in collaboration with A. Ahmed, A. Quisumbing, Z. Hassan, and M. Zobair. 2011. Evaluating the dairy value chain project in Bangladesh: Midterm report. Report submitted to CARE-Bangladesh by the International Food Policy Research Institute, Washington, DC.

Alkire, S., R. Meinzen-Dick, A. Peterman, A. Quisumbing, G. Seymour, and A. Vas. 2013. The Women's Empowerment in Agriculture Index. World Development 52(1): 71-91.

Berhman, J. 2011. HarvestPlus Reaching End Users: Orange-fleshed sweet potato (OFSP) project. Washington, DC: Report of Qualitative Findings from Uganda. Draft. International Food Policy Research Institute.

Berhman, J., A. Dillon, V. Moreira, D. Olney, and A. Pedehombga. 2011. Helen Keller International's Enhanced Homestead Food Production Program in Burkina Faso. Baseline Report, Preliminary Version. Washington, DC: International Food Policy Research Institute.

de Brauw, A., P. Eozenou, D.O. Gilligan, C. Hotz, N. Kumar, C. Loechl, S. McNiven, J.V. Meenakshi, and M. Moursi. 2010. The 
impact of the HarvestPlus Reaching End Users orange fleshed sweet potato project in Mozambique and Uganda. Washington, DC: International Food Policy Research Institute.

Deere, C.D., and C.R. Doss. 2006. The gender asset gap: What do we know and why does it matter? Feminist Economics 12(1-2): $1-50$.

Deere, C.D., A.D. Oduro, H. Swaminathan, and C. Doss. 2013. Property rights and the gender distribution of wealth in Ecuador, Ghana, and India. Journal of Economic Inequality 11(2): 249-265.

Dillon, A., V. Moreira, D. Olney, A. Pedehombga, and E. Quinones. 2012. Helen Keller International's Enhanced Home Food Production Program in Burkina Faso. Final Report. Washington, DC: International Food Policy Research Institute.

Food and Agriculture Organization of the United Nations (FAO). 2011. The state of food and agriculture 2010-2011. Women in agriculture: Closing the gender gap for development. Rome: FAO.

Gilligan, D.O. 2012. Biofortification, agricultural technology adoption, and nutrition policy: Some lessons and emerging challenges. CESifo Economic Studies 58(2): 405-421.

Gilligan, D., N. Kumar, S. McNiven, J.V. Meenakshi, and A.R. Quisumbing. 2014. Bargaining-power and biofortification: The role of gender in adoption of orange sweet potato in Uganda. Discussion Paper No. 1353. Washington, DC: International Food Policy Research Institute.

Haddad, L., J. Hoddinott, and H. Alderman (eds.). 1997. Intrahousehold resource allocation in developing countries: Models, methods, and policy. Baltimore, MD: Johns Hopkins University Press for the International Food Policy Research Institute.

Hillenbrand, E. 2010. Transforming gender in homestead food production. Gender and Development 18(3): 411-425.

Hotz, C., C. Loechl, A. Lubowa, J. Tumwine, G. Ndeezi, A. Masawi, R. Baingana, A. Carriquiry, A. de Brauw, J. Meenakshi, and D. Gilligan. 2012. Introduction of [beta]-carotene-rich orange sweet potato in rural Uganda resulted in increased vitamin A intakes among children and women and improved vitamin A status among children 1-3. Journal of Nutrition 142(10): 1871-1880.

Johnson, N., J. Njuki, E. Waithanji, M. Nhambeto, M. Rogers, and E. Hutchinson. 2013. The gendered impacts of agricultural asset transfer projects: Lessons from the Manica Smallholder Dairy Development Program. CGIAR system-wide program on Collective Action and Property Rights (CAPRi) Working Paper No. 115. Washington, DC: International Food Policy Research Institute.

Kaplinsky, R., and M. Morris. 2000. A handbook for value chain research. London: International Development Research Centre (IDRC).

McKay, A., and E. Perge. 2013. How strong in the evidence for the existence of poverty traps? A multicountry assessment. Journal of Development Studies 49(7): 877-897.

Meinzen-Dick, R., N. Johnson, A. Quisumbing, J. Njuki, J. Behrman, D. Rubin, A. Peterman, and E. Waithanji. 2011. Gender, assets, and agricultural development programs: A conceptual framework. CGIAR system-wide program on Collective Action and Property Rights (CAPRi) Working Paper No. 99. Washington, DC: International Food Policy Research Institute.

Nhambeto, M., and E. Hutchinson. 2011. Gender, agriculture and assets in the smallholder dairy sector in Manica, Mozambique. Mid-term impact assessment of Manica Smallholder Dairy Development Program. Report submitted to the Gender, Agriculture, and Assets Project (GAAP) (September). Washington, DC: International Food Policy Research Institute.

Olney, D., J. Behrman, E. Iruhiriye, M. van den Bold, and A. Pedehombga. 2013. Helen Keller International's Enhanced Homestead Food Production Program in Burkina Faso: Results from a process evaluation. Washington, DC: International Food Policy Research Institute.

Quisumbing, A.R. 2009. Beyond the bari: Gender, groups, and social relations in rural Bangladesh. CAPRi Working Paper No. 96. Washington, DC: International Food Policy Research Institute.

Quisumbing, A.R., S. Roy, J. Njuki, K. Tanvin, and E. Waithanji. 2013. Can dairy value-chain projects change gender norms in rural Bangladesh? Impacts on assets, gender norms, and time use. Discussion Paper No. 1311. Washington, DC: International Food Policy Research Institute.

Rubin, D., and C. Manfre. 2014. Promoting gender-equitable agricultural value chains: Issues, Opportunities, and Next Steps. In Gender in agriculture and food security: Closing the knowledge gap, ed. A. Quisumbing, R. Meinzen-Dick, T. Raney, A. Croppenstedt, J.A. Behrman, and A. Peterman. New York, NY: Springer and FAO.

Schreiner, M., and M. Sherraden. 2007. Can the poor save? Saving and asset building in individual development accounts. New Brunswick, NJ: Transaction Publishers.

van den Bold, M., A. Quisumbing, and S. Gillespie. 2013. Women's empowerment and nutrition: An evidence review. IFPRI Discussion Paper No. 1294. Washington, DC: International Food Policy Research Institute.

Waithanji, E., J. Njuki, T. Kakuly, and P. Muindi. 2012. Expanding dairy production and marketing: CARE Bangladesh Strengthening the Dairy Value Chain Project (SDVCP). Draft under preparation. Nairobi, Kenya: International Livestock Research Institute.

Wang'ombe, J. 2008. The potato value chain in Kenya and Uganda. Unpublished paper. Maastricht, The Netherlands: Maastricht School of Management.

Zvomuya, F. 2009. Gouda goes for gold. Dairy Mail Africa. http:// www.dairymailafrica.co.za/images/acrobat/dma_apr09/tdm_apr09. pdf. Accessed 1 Feb 2012.

Agnes R. Quisumbing Ph.D., is a Senior Research Fellow at the International Food Policy Research Institute (IFPRI). Her research interests include gender and intrahousehold allocation, property rights, intergenerational transfers, and the determinants of long-term economic mobility.

Deborah Rubin Ph.D., is co-owner and Co-Director of Cultural Practice, LLC. Her professional interests include applying qualitative research methods to address gender inequalities in agricultural development, with special attention to value chain operations.

Cristina Manfre M.Sc., is a Senior Associate and partner at Cultural Practice, LLC. Her professional interests include assisting organizations to address gender issues in policies and programs, institutional capacity building on gender integration, and gender and agricultural value chain analysis.

Elizabeth Waithanji Ph.D., is a gender consultant at the International Livestock Research Institute (ILRI), Nairobi, Kenya. Her research interests include gender issues affecting smallholder farmer participation in livestock value chains and integration of gender in livestock bioscience research.

Mara van den Bold M.Sc., is a Research Analyst at the International Food Policy Research Institute (IFPRI), Washington, DC. Her research interests include gender, nutrition, agriculture and agrarian reform, and political ecology. 
Deanna Olney Ph.D., is a Senior Research Fellow in IFPRI's Poverty, Health, and Nutrition Division. Her research interests focus on what impact nutrition-sensitive programs have on women's and children's nutrition, health, development and well-being and how these impacts are achieved and how to further optimize impacts.

Nancy Johnson Ph.D., is a Senior Research Fellow at the International Food Policy Research Institute (IFPRI). Her research interests include the impacts of agricultural research on food production, poverty and the environment.

Ruth Meinzen-Dick Ph.D., is a Senior Research Fellow at the International Food Policy Research Institute (IFPRI). Her research interests include collective action, property rights, water management, and gender. 